\title{
Green crab Carcinus maenas symbiont profiles along a North Atlantic invasion route
}

\author{
Jamie Bojko, ${ }^{1,2}$, Paul D. Stebbing ${ }^{3}$, Alison M. Dunn ${ }^{1}$, Kelly S. Bateman ${ }^{2,4}$, \\ Fraser Clark ${ }^{5}$, Rose C. Kerr ${ }^{2,4}$, Sarah Stewart-Clark ${ }^{6}$, Ása Johannesen ${ }^{7}$, \\ Grant D. Stentiford ${ }^{2,4, *}$ \\ ${ }^{1}$ Faculty of Biological Sciences, University of Leeds, Leeds LS2 9JT, UK \\ ${ }^{2}$ Pathology and Microbial Systematics, Centre for Environment, Fisheries and Aquaculture Science (Cefas), \\ Weymouth Laboratory, Weymouth, Dorset DT4 8UB, UK \\ ${ }^{3}$ Epidemiology and Risk, Centre for Environment, Fisheries and Aquaculture Science (Cefas), Weymouth Laboratory, \\ Weymouth, Dorset DT4 8UB, UK \\ ${ }^{4}$ European Union Reference Laboratory for Crustacean Diseases, Centre for Environment, \\ Fisheries and Aquaculture Science (Cefas), Weymouth Laboratory, Weymouth, Dorset DT4 8UB, UK \\ ${ }^{5}$ Department of Chemistry and Biochemistry, Mount Allison University, Sackville New Brunswick E4L 1E4, Canada \\ ${ }^{6}$ Faculty of Agriculture, Dalhousie University, 58 River Road, Truro, Nova Scotia B2N 5E3, Canada \\ ${ }^{7}$ Fiskaaling P/F, Við Áir, Hvalvík 430, Faroe Islands
}

\begin{abstract}
The green crab Carcinus maenas is an invader on the Atlantic coast of Canada and the USA. In these locations, crab populations have facilitated the development of a legal fishery in which C. maenas is caught and sold, mainly for use as bait to capture economically important crustaceans such as American lobster Homarus americanus. The paucity of knowledge on the symbionts of invasive C. maenas in Canada and their potential for transfer to lobsters poses a potential risk of unintended transmission. We carried out a histological survey for symbionts of $C$. maenas from their native range in Northern Europe (in the UK and Faroe Islands), and invasive range in Atlantic Canada. In total, 19 separate symbiotic associations were identified from C. maenas collected from 27 sites. These included metazoan parasites (nematodes, Profilicollis botulus, Sacculina carcini, Microphallidae, ectoparasitic crustaceans), microbial eukaryotes (ciliates, Hematodinium sp., Haplosporidium littoralis, Ameson pulvis, Parahepatospora carcini, gregarines, amoebae), bacteria (Rickettsia-like organism, milky disease), and viral pathogens (parvolike virus, herpes-like virus, iridovirus, Carcinus maenas bacilliform virus and a haemocyteinfecting rod-shaped virus). Hematodinium sp. were not observed in the Canadian population; however, parasites such as Trematoda and Acanthocephala were present in all countries despite their complex, multi-species lifecycles. Some pathogens may pose a risk of transmission to other decapods and native fauna via the use of this host in the bait industry, such as the discovery of a virus resembling the previously described white spot syndrome virus (WSSV), B-virus and 'rodshaped virus' (RV-CM) and amoebae, which have previously been found to cause disease in aquaculture (e.g. Salmo salar) and fisheries species (e.g. H. americanus).
\end{abstract}

KEY WORDS: Virus $\cdot$ Neoparamoeba $\cdot$ Microsporidia $\cdot$ Hematodinium $\cdot$ Pathogen-acquisition Homarus americanus $\cdot$ Profilicollis botulus $\cdot$ Non-native species

\section{INTRODUCTION}

Non-native species have been identified as a pathway for the introduction of disease, carrying their parasites to novel locations and potentially infecting native susceptible fauna (Dunn \& Hatcher 2015,

${ }^{*}$ Corresponding author: grant.stentiford@cefas.co.uk
Bojko et al. 2017b, Roy et al. 2017). Alternatively, maintaining or acquiring parasitic infections may result in a form of regulation through co-introduction for invasive populations, potentially controlling population size and limiting the impact of the invader (Kuris et al. 2005). In other cases, invaders may es-

(C) The authors 2018. Open Access under Creative Commons by Attribution Licence. Use, distribution and reproduction are unrestricted. Authors and original publication must be credited. 
cape their native parasites and may benefit from the lack of infection and disease; a phenomenon categorised as 'parasite release' (Torchin et al. 2003), evidence for which is lacking for many marine organisms. Parasite release has recently been the focus of a review of 31 marine species (Blakeslee et al. 2013). One example includes Carcinus maenas, for which parasite release has been well researched (Torchin et al. 2001, 2002, Blakeslee et al. 2015).

The European shore crab C. maenas is associated with a wide range of symbiotic fauna in both its native and invasive ranges, much of which is reviewed in Shields et al. (2015), but also includes chordates, bryozoans (McIntosh 1865, Duerden 1893, Richard 1899), crustaceans, helminths (McIntosh 1865, von Linstow 1878, Monticelli 1890, Hall 1929, Rankin 1940, Bourdon 1965, James 1969, Prévot \& Deblock 1970, Vivares 1971, Moravec 2007, Pina et al. 2011), protists (Chatton \& Lwoff 1935, Couch 1983, Stentiford et al. 2004), fungi (Cuénot 1895, Bojko et al. 2017a), bacteria (Perkins 1967, Comely \& Ansell 1989, Eddy et al. 2007) and viruses (Sindermann 1990, Stentiford \& Feist 2005, Bateman \& Stentiford 2017). Often, in-depth knowledge of the symbionts carried by invasive organisms is lacking (Roy et al. 2017). The detailed knowledge of symbiont associations for C. maenas offers a suitable host system to facilitate studies of symbiont movement and dispersal along aquatic invasion pathways, possibly accounting for parasite release (Torchin et al. 2003).

C. maenas has successfully invaded a multitude of coastal habitats across the globe, and genetic studies have defined some of the pathways via which this species has spread (Darling et al. 2008, Blakeslee et al. 2010). One such pathway involves a proposed translocation of crabs from sites within Northern Europe to Atlantic Canada, as determined by host microsatellite analysis (Darling et al. 2008). C. maenas can significantly alter native biodiversity and coastal operations (e.g. molluscan aquaculture) within its invasive range (Therriault et al. 2008). Invasive populations of $C$. maenas can destroy eel grass beds (Garbary et al. 2014), consume native shellfish, polychaetes and infauna (Gregory \& Quijón 2011), and displace populations of native rock crabs. Their significant physical impact on ecosystems classifies them as ecosystem engineers (Crooks 2002). In an attempt to reduce the population size of invasive C. maenas, the Canadian Government has issued 'green crab licences' that permit the harvesting of large numbers of crabs to use and sell as bait for commercial fishing of other crustaceans (such as the lobster Homarus americanus) (DFO 2017a). As sea temperatures continue to warm, this species has been moving northward, colonising further coastlines, possibly carrying with them other symbionts (Blakeslee et al. 2010).

Given that no comprehensive surveys of symbionts have occurred in Canadian populations of C. maenas to date, it is pertinent to consider the potential for pathogen transfer between crab and lobster via the authorised practice of bait use. Transmission of pathogens from an invasive to native host has been documented on several occasions, including the transmission of gaffkaemia and crayfish plague (Stebbing et al. 2012, Dunn \& Hatcher 2015); all of which have had a devastating impact on native populations. The lobster fishery industry in Atlantic Canada is of great economic importance and was worth $\$ 2.0$ billion USD in 2016 (DFO 2017b), providing an important incentive to assess the risk posed by invasive hosts and their parasites upon the native $H$. americanus population.

This study aimed to determine the symbiont (pathogen, parasite, commensal) profile of C. maenas populations at 3 geographically distinct locations in the Northern Atlantic: 2 native areas from Northern Europe (UK, Faroe Islands) and the invasion site Nova Scotia, in Atlantic Canada. By conducting a comprehensive screening programme based upon histology, transmission electron microscopy and molecular diagnostics, we demonstrate differential presence and prevalence of numerous symbionts and discuss their potential risk as invasive pathogens in Canadian marine systems.

\section{MATERIALS AND METHODS}

\section{Sampling and dissection}

Carcinus maenas were sampled from shoreline sites in the UK ( $\mathrm{n}=15$ sites), Faroe Islands (5 sites) and Atlantic Canada ( 7 sites) (Fig. 1, Table 1). In addition to samples collected during this study, we also utilised data relating to previous histopathology surveys of $C$. maenas conducted in the UK by the Centre for Environment, Fisheries and Aquaculture Science (Cefas) dating back to 2010 (Table 1). In all cases, crabs were either captured by baited traps set near to shore, or in most cases, by hand collection from the shoreline. After collection, animals were transported to 1 of 3 laboratories: Cefas (UK), Fiskaaling (Faroe Islands) or Dalhousie Agriculture Campus (Canada), where they were euthanized on 


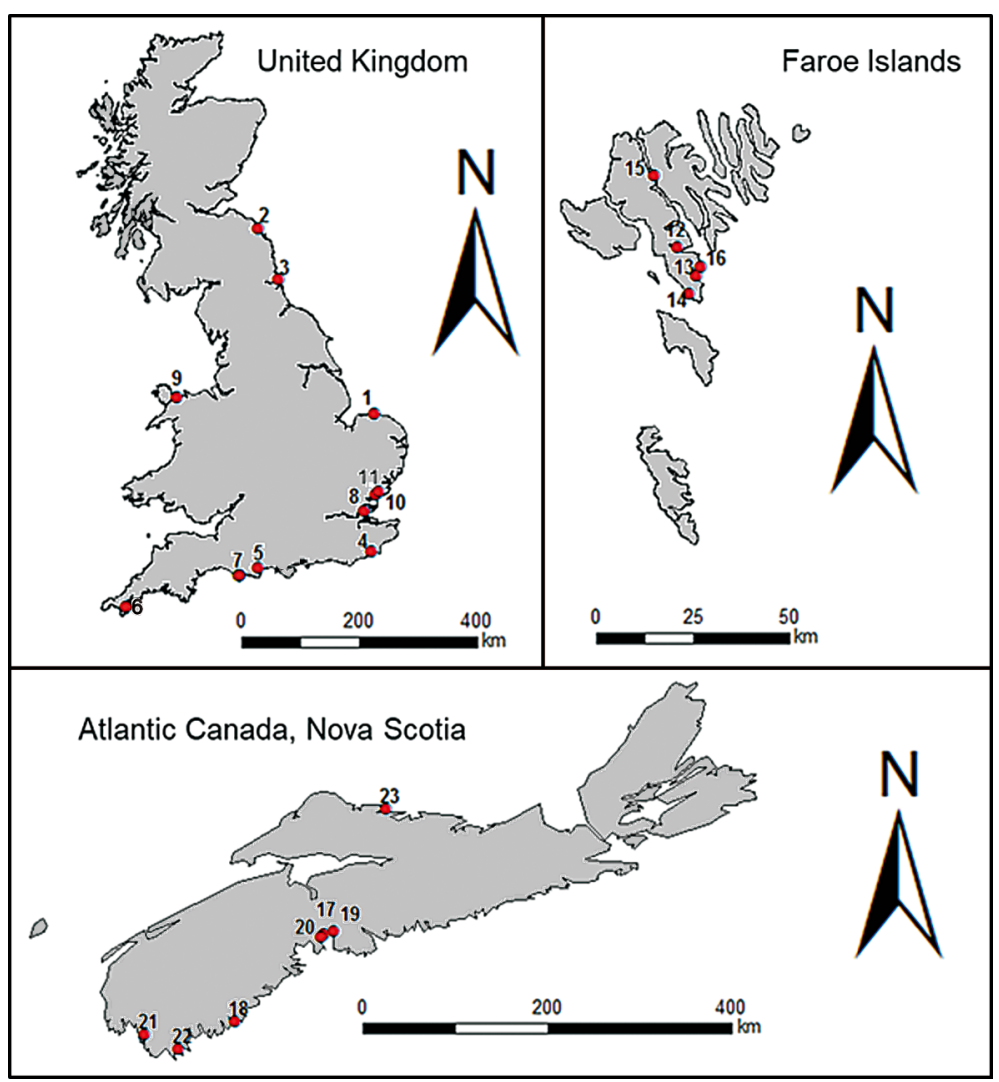

Fig. 1. Sample sites used during the study, including the UK, Faroe Islands and Nova Scotia. Numbers of each site correspond with those in Table 1. Map was drawn and annotated in ArcGIS v.10.4.1, and line drawings of the countries were attained from www.arcgis.com (@ crown copyright projection Transverse Mercator)

ice and dissected to provide gill, heart, muscle, hepatopancreas and gonad tissues for histology, electron microscopy and molecular diagnostics, using procedures defined by the European Union Reference Laboratory (EURL) for Crustacean Diseases (www.crustaceancrl.eu). Animals collected post-2013 that were below $22 \mathrm{~mm}$ carapace width were halved to provide histological and ethanol-fixed material. Animals below $15 \mathrm{~mm}$ carapace width were fixed whole for histology.

\section{Histological processing and screening}

For histology, organs and tissues were placed in Davidson's seawater fixative (DSF) (Hopwood 1996) for $48 \mathrm{~h}$ prior to their transfer to $70 \%$ ethanol or industrial methylated spirit. Samples were wax infiltrated using an automated tissue processor (Peloris; Leica Microsystems) prior to embedding in wax blocks. Blocks were trimmed and then cut to provide a single section between 3 and $4 \mu \mathrm{m}$ thickness using a Finesse (E/NE) Rotary Microtome (Leica). Sections were mounted on glass slides, stained with haematoxylin and alcoholic eosin (H\&E) and cover-slipped with xylene. Stained slides were read and imaged via a Nikon Eclipse (E800) light microscope and images obtained using on-board digital imaging software at the Cefas Weymouth Laboratory. Histopathology was used as the primary screening tool in this study, and was used to estimate immune response to any symbionts based on histological observations, such as melanisation reactions and haemocyte aggregation.

\section{Transmission electron microscopy}

Organ and tissue samples collected for transmission electron microscopy (TEM) were fixed in $2.5 \%$ glutaraldehyde in $0.1 \%$ cacodylate buffer and stored until required. When a pathogen was identified via histology, the corresponding TEM sample for the same specimen was processed for TEM analysis. Briefly, samples were soaked in sodium cacodylate buffer twice over a 10 min period and stained with $1 \%$ osmium tetroxide $\left(\mathrm{OsO}_{4}\right)$ solution for $1 \mathrm{~h}$ prior to infiltration with acetone and infusion with Agar100 resin. Individual samples were placed in moulds $\left(\sim 1 \mathrm{~cm}^{3}\right)$ with fresh resin and polymerised at $60^{\circ} \mathrm{C}$ for $16 \mathrm{~h}$. The resulting blocks were trimmed with a razor blade to expose the surface of the sample and sectioned at $1 \mu \mathrm{m}$ thickness (stain: Toluidine Blue) with a glass knife. Ultra-thin sections were cut from the same block at $\sim 80 \mathrm{~nm}$ thickness using a diamond knife. Sections were stained with uranyl acetate and Reynolds lead citrate (Reynolds 1963) prior to analysis on a JEM 1400 transmission electron microscope (JEOL). Digital images were captured using an AMT XR80 camera and AMT V602 software (Advanced Microscopy Techniques). In addition, one sample displaying a putative viral infection, and for which a corresponding TEM sample was not available, was removed from the wax block using Histosolve and taken to water via an ethanol-water dilution series before being re-fixed in $2.5 \%$ glutaraldehyde in $0.1 \%$ cacodylate buffer. The process then continued as described above. 
Table 1. Date, geographic location (see Fig. 1), coordinates and sample size of Carcinus maenas involved in the disease screening process

\begin{tabular}{|c|c|c|c|c|c|}
\hline Country & $\begin{array}{l}\text { Site location } \\
\quad \text { (Fig. 1) }\end{array}$ & Sample site & Coordinates & $\begin{array}{l}\text { Sample date } \\
\text { (mm/уууу) }\end{array}$ & $\mathrm{n}$ \\
\hline \multirow[t]{15}{*}{ UK } & 1 & Blakeney Harbour, Norfolk & $52.964^{\circ} \mathrm{N}, 0.964^{\circ} \mathrm{E}$ & $07 / 2010$ & 30 \\
\hline & 2 & Berwick upon Tweed & $55.769^{\circ} \mathrm{N}, 2.009^{\circ} \mathrm{W}$ & $08 / 2010$ & 30 \\
\hline & 3 & North Shields & $55.008^{\circ} \mathrm{N}, 1.433^{\circ} \mathrm{W}$ & $08 / 2010$ & 30 \\
\hline & 4 & Rye Harbour & $50.930^{\circ} \mathrm{N}, 0.772^{\circ} \mathrm{E}$ & $08 / 2010$ & 30 \\
\hline & 5 & Poole Harbour & $50.708^{\circ} \mathrm{N}, 2.000^{\circ} \mathrm{W}$ & $08 / 2010$ & 30 \\
\hline & 6 & Helford & $50.096^{\circ} \mathrm{N}, 5.136^{\circ} \mathrm{E}$ & $08 / 2010$ & 30 \\
\hline & 7 & Newtons Cove, Weymouth & $50.605^{\circ} \mathrm{N}, 2.449^{\circ} \mathrm{E}$ & $08 / 2010$ & 26 \\
\hline & 8 & Southend on Sea & $51.533^{\circ} \mathrm{N}, 0.627^{\circ} \mathrm{W}$ & $09 / 2010$ & 30 \\
\hline & 9 & Menai Straits & $53.246^{\circ} \mathrm{N}, 4.067^{\circ} \mathrm{W}$ & 09/2010 & 30 \\
\hline & 10 & West Mersey & $51.773^{\circ} \mathrm{N}, 0.900^{\circ} \mathrm{E}$ & $10 / 2010$ & 30 \\
\hline & 7 & Weymouth, The Nothe & $50.605^{\circ} \mathrm{N}, 2.449^{\circ} \mathrm{W}$ & $06 / 2012$ & 188 \\
\hline & 11 & West Mersea Island & $51.804^{\circ} \mathrm{N}, 1.000^{\circ} \mathrm{E}$ & $10 / 2012$ & 120 \\
\hline & 7 & Weymouth, The Nothe & $50.605^{\circ} \mathrm{N}, 2.449^{\circ} \mathrm{W}$ & $11 / 2012$ & 8 \\
\hline & 7 & Weymouth, The Nothe & $50.605^{\circ} \mathrm{N}, 2.449^{\circ} \mathrm{W}$ & $02 / 2013$ & 10 \\
\hline & 7 & Weymouth, The Nothe & $50.605^{\circ} \mathrm{N}, 2.449^{\circ} \mathrm{W}$ & $11 / 2013-03 / 2014$ & 146 \\
\hline \multirow[t]{5}{*}{ Faroe Islands } & 12 & Kaldbaksfjørður & $62.058^{\circ} \mathrm{N}, 6.875^{\circ} \mathrm{W}$ & 07/2014-08/2014 & 23 \\
\hline & 13 & Argir & $61.997^{\circ} \mathrm{N}, 6.770^{\circ} \mathrm{W}$ & $08 / 2014$ & 21 \\
\hline & 14 & Kirkjubøur & $61.953^{\circ} \mathrm{N}, 6.798^{\circ} \mathrm{W}$ & $08 / 2014$ & 25 \\
\hline & 15 & Nesvík & $62.216^{\circ} \mathrm{N}, 7.016^{\circ} \mathrm{W}$ & $08 / 2014$ & 181 \\
\hline & 16 & Tórshavn & $62.018^{\circ} \mathrm{N}, 6.754^{\circ} \mathrm{W}$ & $08 / 2014$ & 56 \\
\hline \multirow[t]{7}{*}{ Canada } & 17 & Port L'Hebert & $43.801^{\circ} \mathrm{N}, 64.932^{\circ} \mathrm{W}$ & $08 / 2014$ & 41 \\
\hline & 18 & Hubbards & $44.642^{\circ} \mathrm{N}, 64.051^{\circ} \mathrm{W}$ & $08 / 2014$ & 62 \\
\hline & 19 & Boutiliers Point & $44.659^{\circ} \mathrm{N}, 63.952^{\circ} \mathrm{W}$ & $08 / 2014$ & 20 \\
\hline & 20 & Fox Point & $44.611^{\circ} \mathrm{N}, 64.058^{\circ} \mathrm{W}$ & $08 / 2014$ & 22 \\
\hline & 21 & Pubnico & $43.702^{\circ} \mathrm{N}, 65.783^{\circ} \mathrm{W}$ & $08 / 2014$ & 111 \\
\hline & 22 & River Port & $43.624^{\circ} \mathrm{N}, 65.484^{\circ} \mathrm{W}$ & $08 / 2014$ & 42 \\
\hline & 23 & Malagash & $45.813^{\circ} \mathrm{N}, 63.473^{\circ} \mathrm{W}$ & $08 / 2014$ & 134 \\
\hline
\end{tabular}

\section{Molecular techniques}

Where a pathogen of interest was identified via histology and TEM, a sample from the same specimen was processed for molecular diagnostics and systematics; those selected are reflected in the primer sets used in Table 2. DNA was extracted via a conventional phenol-chloroform method after initial digestion with Lifton's buffer $(0.1 \mathrm{M}$ Tris- $\mathrm{HCl}, 0.5 \%$ SDS, $0.1 \mathrm{M}$ EDTA), or via the EZ1 automated DNA extraction using manufacturer's instructions (Qiagen). The resulting DNA extract was tested with appropriate primer sets and reaction conditions for the pathogen type in question via a PCR diagnostic method detailed in Table 2. In all cases a single PCR reaction $(50 \mu l)$ included the following components: $1.25 \mathrm{U}$ of Taq polymerase, $2.5 \mathrm{mM} \mathrm{MgCl}_{2}, 0.25 \mathrm{mM}$ of each dNTP, $1 \mu \mathrm{M}$ of each primer, $1 \times$ flexi buffer and $2.5 \mu \mathrm{l}$ of DNA template (30 to $100 \mathrm{ng} \mathrm{pl}^{-1}$ ). Amplicons were visualised using a $2 \%$ agarose gel $(120 \mathrm{~V}, 45 \mathrm{~min})$. Where appropriate, amplicons of correct size were extracted from the gel, purified for sequencing using spin columns and ethanol precipitation, and sequenced via the Eurofins sequencing barcode service (https://www.eu- rofinsgenomics.eu/). Sequence data for Neoparamoeba sp. and Hematodinium sp. has been submitted to NCBI (MG761749-MG761755).

\section{Phylogenetic analysis of amoebae SSU rRNA gene sequence}

Amoebae symbioses in shore crabs are a novel finding, and after initial histological identification followed by PCR diagnostics to further identify their species, phylogenetic analysis was used to compare these isolates with other crustacean-infecting species.

Sequence similarity searches were used to compare 5 amoebae small subunit (SSU) rDNA isolates from Atlantic Canada (Nova Scotia) and the Faroe Islands to available sequence isolates (NCBI: BLASTn), identifying the most similar species to be Neoparamoeba pemaquidensis, N. branchiphila and N. perurans. Example sequences from each species $(N$. pemaquidensis: EU884494; N. branchiphila: HQ13 2925; N. perurans: EF216899) were used to compare the phylogeny of the C. maenas isolates, alongside an outgroup containing 2 Vanella sp., Vexillifera 
Table 2. Forward and reverse primer sequences used for the amplification of several parasite and pathogen groups via PCR from genomic template, extracted from host and parasite/pathogen tissues. TC: thermocycling. Each PCR run included an initial 5 min denaturation step and a 5 min final extension step, according to the first and final temperatures, respectively, noted in the Tc (thermocycler) settings. The amplification stage consisted of 35 cycles of all 3 temperatures in the Tc settings, with each temperature being held for $1 \mathrm{~min}$.

\begin{tabular}{|c|c|c|c|c|c|c|}
\hline Infection & Dir. & Name & $\begin{array}{l}\text { Primer } \\
\text { Sequence }\left(5^{\prime}-3^{\prime}\right)\end{array}$ & $\begin{array}{l}\text { Tc settings } \\
\left({ }^{\circ} \mathrm{C}\right)\end{array}$ & $\begin{array}{l}\text { Amplicon } \\
\text { size (bp) }\end{array}$ & Reference \\
\hline \multicolumn{7}{|c|}{ Microsporidia } \\
\hline $1^{\text {st }}$ round & $\begin{array}{l}\text { Fwd } \\
\text { Rev }\end{array}$ & $\begin{array}{l}\text { MF1 } \\
\text { MR1 }\end{array}$ & $\begin{array}{l}\text { CCG GAG AGG GAG CCT GAG A } \\
\text { GAC GGG CGG TGT GTA CAA A }\end{array}$ & $95-55-72$ & $800-900$ & $\begin{array}{l}\text { Tourtip et al. } \\
\text { (2009) }\end{array}$ \\
\hline $2^{\text {nd }}$ round & $\begin{array}{l}\text { Fwd } \\
\text { Rev }\end{array}$ & $\begin{array}{l}\text { V1F } \\
1492 \mathrm{r}\end{array}$ & $\begin{array}{l}\text { CAC CAG GTT GAT TCT GCC TGA C } \\
\text { CCA TGT TAC GAC TTA CAT CC }\end{array}$ & $95-45-72$ & $1400-1500$ & $\begin{array}{l}\text { Vossbrinck } \\
\text { et al. (1998) }\end{array}$ \\
\hline \multicolumn{7}{|l|}{ Amoebae } \\
\hline $1^{\text {st }}$ round & $\begin{array}{l}\text { Fwd } \\
\text { Rev }\end{array}$ & $\begin{array}{l}\text { F1 } \\
\text { R1 }\end{array}$ & $\begin{array}{l}\text { TAT GGT GAA TCA TGA TAA CTT WAC } \\
\text { TCT CCT TAC TAG ACT TTC AYK }\end{array}$ & $95-55-72$ & $300-500$ & Unpubl. \\
\hline $2^{\text {nd }}$ round & $\begin{array}{l}\text { Fwd } \\
\text { Rev }\end{array}$ & $\begin{array}{l}\text { F2 } \\
\text { R1 }\end{array}$ & $\begin{array}{l}\text { AAT CAT GAT AAC TTW ACG AAT CG } \\
\text { TCT CCT TAC TAG ACT TTC AYK }\end{array}$ & $95-54-72$ & $300-500$ & Unpubl. \\
\hline \multicolumn{7}{|c|}{ Hematodinium } \\
\hline $1^{\text {st }}$ round & $\begin{array}{l}\text { Fwd } \\
\text { Rev }\end{array}$ & $\begin{array}{l}\text { 2009ITS1F } \\
\text { 2009ITS1\&2R }\end{array}$ & $\begin{array}{l}\text { AAC CTG CGG AAG GAT CAT TC } \\
\text { TAG CCT TGC CTG ACT CAT G }\end{array}$ & $94-60-72$ & 500 & $\begin{array}{l}\text { H. J. Small } \\
\text { (pers. comm.) }\end{array}$ \\
\hline $2^{\text {nd }}$ round & $\begin{array}{l}\text { Fwd } \\
\text { Rev }\end{array}$ & $\begin{array}{l}\text { 2009ITS1F } \\
\text { 2009ITS1R }\end{array}$ & $\begin{array}{l}\text { AAC CTG CGG AAG GAT CAT TC } \\
\text { CCG AGC CGA GGC ATT CAT CGC T }\end{array}$ & $94-60-72$ & 350 & $\begin{array}{l}\text { H. J. Small } \\
\text { (pers. comm.) }\end{array}$ \\
\hline
\end{tabular}

armata and 2 Korotnevella sp. as used in the initial description of $N$. perurans (Young et al. 2007). Sequence data were aligned using Clustal W with default settings in MEGA7 v.7.0.21 (Kumar et al. 2016) and 2 trees were constructed using either neighbour-joining (NJ) (Tamura-3-parameter method with gamma-distributed rate heterogeneity; Tamura 1992) (Saitou \& Nei 1987) or maximum likelihood (ML) (general time reversible model; Nei \& Kumar 2000) methods. Clade credibility was assessed in the resulting trees using 1000 bootstrap tests (Felsenstein 1985), and annotated onto the maximum likelihood tree using both methods (NJ/ML).

\section{Statistical analyses}

C. maenas symbiont data was recorded in a binomial manner, where the presence of a particular symbiont in an individual was allocated a score of either ' 1 ' (present) or ' 0 ' (absent). Data from populations collected at each of the 27 sites at 3 geographic locations (UK, Faroe Islands, Canada) was analysed using R v.3.2.1 (R Core Team 2014) via RStudio interface to apply the Marascuilo procedure to each population, which compares the prevalence of specific symbionts between sites and their respective sample sizes. The Marascuilo procedure highlights significant differences $(p<0.05)$ between population prevalence, which was conducted using a Pearson's chi-squared test with Yates' continuity correction.
Using the entire dataset, host sex ratios were compared with the presence of symbionts to identify any sex bias towards infection prevalence. Host sex was also compared with the number of symbionts present using non-parametric statistics (Wilcoxon test).

\section{RESULTS}

\section{Symbiont profiles of Carcinus maenas populations by country}

United Kingdom

Histological analyses revealed 14 symbionts in crabs collected from UK sites. Observations included metazoan parasites, microbial eukaryotes, bacteria and viruses.

An acanthocephalan, Profilicollis botulus, was observed in $3.3 \%$ of the population sampled from Blakeney Harbour, Norfolk, UK. Acanthella infection stages were noted upon dissection, identified based on morphology and host, and infection was assessed using histology. The mid-gut of infected specimens contained acanthocephalans, presumably acquired from the faeces of an avian host. Infection resulted in an enlarged gut due to the presence of the parasite (Fig. 2a). Sacculina carcini was observed infecting crabs from 5 of the UK sites, at a mean prevalence of $3.1 \pm 5.8 \%$ (Table 3 ). Trematodes belonging to the Microphallidae were observed infecting crabs from 


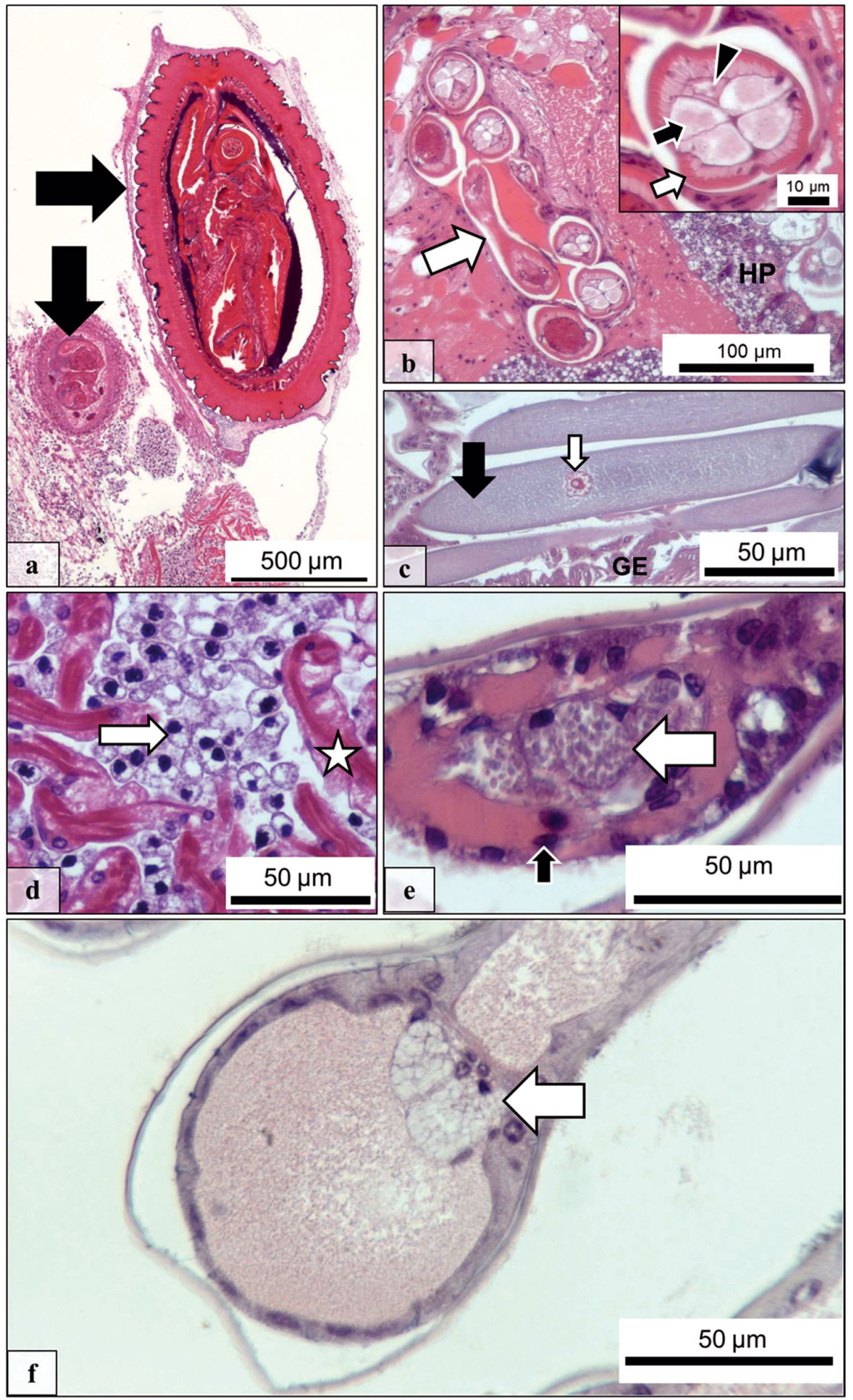

Fig. 2. Parasites, pathogens and commensals of Carcinus maenas. (a) Profilicollis botulus in the mid-gut of its host; black arrows indicate parasites. (b) A nematode (white arrow) encysted into the connective tissue of the host; inset shows a section through the parasite in high detail, determining 5 body cavities (black arrow/triangle) and surrounding smooth muscle (white arrow). (c) Gregarine parasites (black arrow) with a distinguishable nucleus (white arrow) in the gut lumen of the host. (d) Hematodinium sp. (white arrow) in the haemolymph amongst the heart tissue (white star). (e) Host gill filament (black arrow) with amoebae present in the lumen of the gill with possible hyperparasites (white arrow). (f) Amoebae within the gill filament without hyperparasites; amoebae are membranous and indicated by a white arrow 


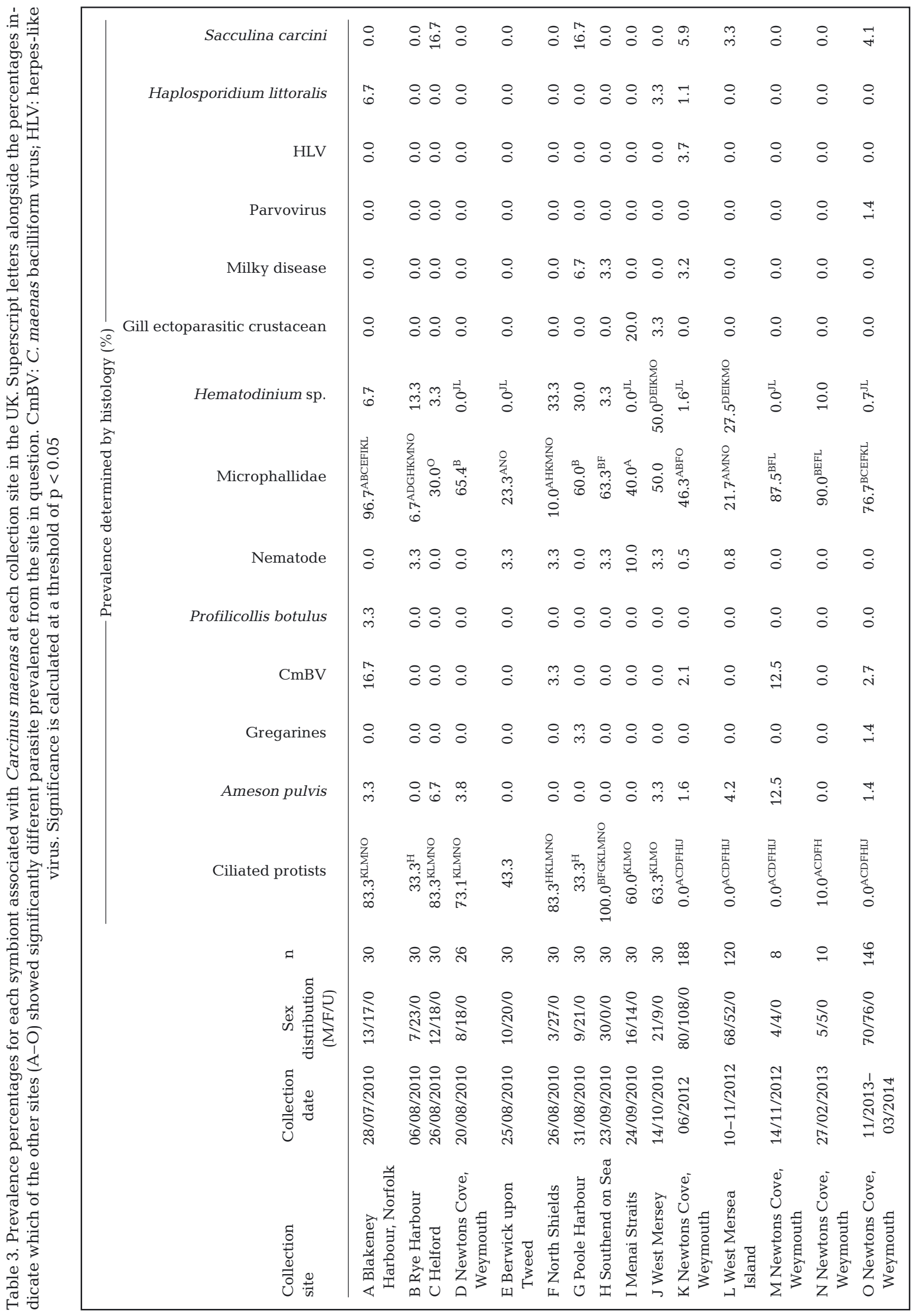


all sites, with a mean prevalence of $51.1 \pm 29.1 \%$ (Table 3). Unidentified nematode parasites were recorded at 8 of the UK sites at a mean $( \pm \mathrm{SD})$ prevalence of $1.9 \pm 2.7 \%$ (Table 3 ). Nematodes were encysted within a variety of tissues (muscle, hepatopancreas, gonad, connective tissue) in their host, but no evidence of a host immune response was observed (Fig. 2b). The presence of ectoparasitic crustaceans (possibly isopods or copepods) of unknown identity were noted via histology in crabs collected from 2 UK sites with a mean prevalence of $1.6 \pm 5.2 \%$ (Table 3). The crustacean ectoparasites were also present at high burden, with 8 to 20 individuals between each gill filament, but were not associated with any observable host immune response.

Several micro-eukaryote symbionts were observed. Gregarine parasites were recorded in crabs from 2 UK sites, at a mean prevalence of $0.3 \pm 0.9 \%$ (Table 3 ). Gregarines colonised the gut lumen, often at high burden (Fig. 2c). The presence of gregarines did not appear to illicit any observable immune response. A microsporidian resembling the Ameson pulvis (cf. Nadelspora sp.) previously described in this host was observed infecting crabs from 7 sites, at a mean prevalence of $2.5 \pm 3.5 \%$ (Table 3 ). This parasite infected its host in the same manner described by Stentiford et al. (2013a); undergoing dimorphic development culminating in needle-like spores infecting mainly heart myofibres and oval Ameson-like spores in the skeletal musculature. Melanisation and phagocytic uptake of microsporidian spores was also observed. The haplosporidian Haplosporidium littoralis was observed in crabs from 3 sites, at a mean prevalence of $0.7 \pm 1.9 \%$ (Table 3 ). The pathology caused by this parasite included infection of the musculature and blood stream and was identical to that described by Stentiford et al. (2013b). Hematodinium sp., a dinoflagellate parasite of $C$. maenas, was observed infecting crabs from 11 sites, at a mean prevalence of $12.0 \pm 15.7 \%$ (Fig. 2d, Table 3). Ciliated protists, often alongside filamentous bacteria, possibly Mesomycetozoea and detritus, were a common commensal observed colonising the space between gill lamellae and more generally on the carapace and appendages of crabs collected from 11 sites at a mean prevalence of $44.4 \pm 36.2 \%$ (Table 3 ). The presence of these commensals caused no discernible pathology.

Bacterial infections were characterised by a previously described condition termed 'milky disease', a systemic bacterial infection of the haemolymph (Eddy et al. 2007). It was detected in an average $0.9 \pm$ $2.0 \%$ collected from the Newtons Cove collections in Weymouth. Large bacterial plaques occurred within the haemolymph and within fixed phagocytes of the hepatopancreas and gill. Infection was often accompanied by a pronounced host response, including melanisation.

Several viral pathogens were observed in crabs collected from UK sites. A herpes-like virus (HLV) of C. maenas was recorded in $3.7 \%$ of animals from on collection from the Newtons Cove site in Weymouth. Infection was apparently restricted to granulocytes and hematopoietic tissues and resulted in hypertrophy of the nucleus (Fig. 3a). In some cases, infected cells were binucleate. TEM revealed membranebound virions with a central genomic core (Fig. 3b). Virions measured $112.4 \pm 19.4 \mathrm{~nm}(\mathrm{n}=13)$ in diameter. The central genomic core measured $67.8 \pm$ $12.5 \mathrm{~nm}(\mathrm{n}=13)$ in length and $28.2 \pm 6.1 \mathrm{~nm}(\mathrm{n}=13)$ in width. This infection appeared not to elicit any targeted host immune response. A putative parvo-like virus infection was identified from $1.4 \%$ of specimens collected in the 2013-2014 sample from Newtons Cove, Weymouth. The virus caused nuclear hypertrophy in haemocytes and gill epithelial cells, often in the form of a Cowdry-like body (Fig. 3c). Under TEM, infected cells exhibited a viroplasm containing hexagonal virions that measured $89.6 \pm$ $18.9 \mathrm{~nm}(\mathrm{n}=15)$ in diameter (Fig. 3d). No immune response was observed toward infected host cells. Finally, Carcinus maenas bacilliform virus (CmBV) was observed in the hepatopancreas of C. maenas sampled from 5 UK sites at an average prevalence of $2.5 \pm 5.1 \%$ (Table 3, Fig. 3e,f). Infection was restricted to the nuclei of hepatopancreatic epithelial cells, and although infected cells were observed sloughing from the basement membrane, no apparent immune response was observed. These observations are consistent with those described by Stentiford \& Feist (2005).

\section{The Faroe Islands}

Histological analyses revealed 13 symbionts in crabs collected from Faroe Island sites. Several of these corresponded to those detected in crabs collected from sites in the UK. In addition, we identified 2 novel virus infections and colonisation by an amoeba not detected in samples from the UK.

Metazoan parasites included a second observation of an ectoparasitic crustacean on the gills of crabs from the Nesvík and Tórshavn sites, at an average prevalence of $0.9 \pm 1.6 \%$ (Table 4 ). P. botulus acanthella were detected in the gut of crabs collected at all sites, at an average prevalence of $10.5 \pm 8.4 \%$ 

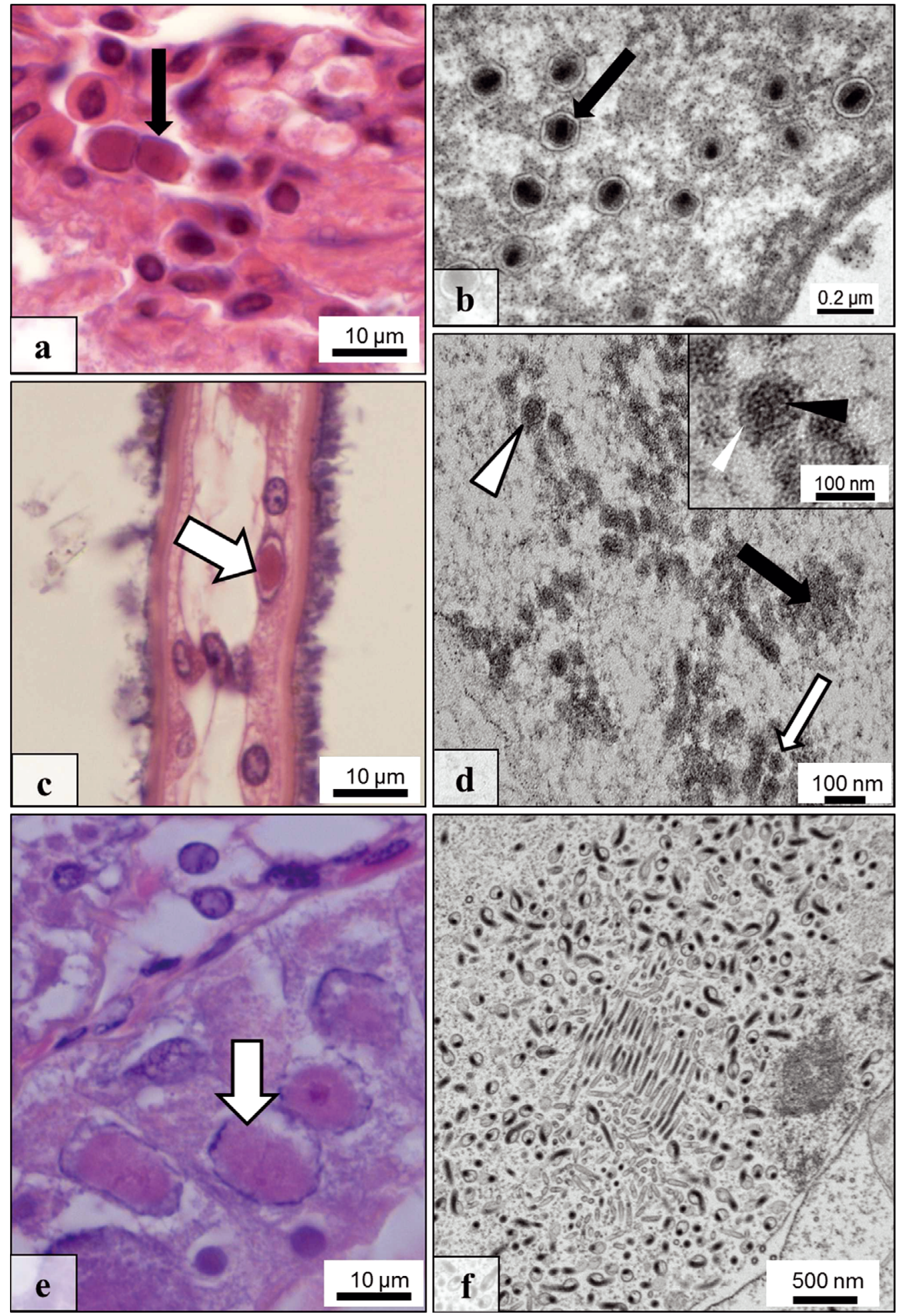

Fig. 3. Viruses from Carcinus maenas in the UK. (a) Histological section of infected (black arrow) and uninfected granulocytes in the haemolymph. (b) Transmission micrograph of the nucleus of an infected granulocyte; individual virions (black arrow) are present. (c) Histological section of a gill lamella, where some epithelia have nuclei with Cowdry bodies (white arrow). (d) High magnification image of developing virions (white arrow) and viral proteins (black arrow); some are developed (white triangle). Inset image identifies the core (black triangle) and extremity (white triangle) of the virus. (e) Histopathology of $C$. maenas bacilliform virus (CmBV), where hepatopancreatocytes are present with a nucleus filled with viroplasm (white arrow). (f) Transmission electron micrograph of CmBV virions in the nucleus of the host cell 


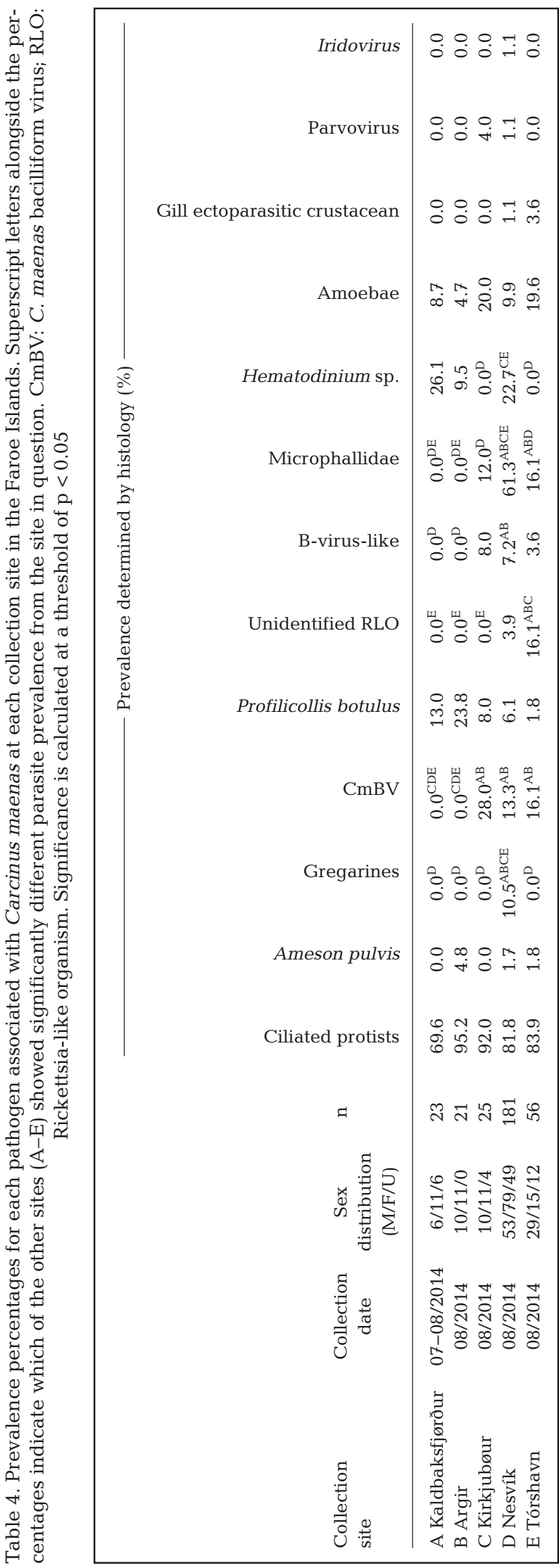

(Table 4, Fig. 2a). In histology, acanthocephala elicited a melanisation response in cases where infection breached the gut epithelium. Trematodes belonging to the Microphallidae were detected in crabs from 3 sites, at an average prevalence of $17.9 \pm$ $25.3 \%$ (Table 4 ), displaying the same pathology and visible host immune response as UK populations.

Micro-eukaryote symbionts were frequently observed. Gut-dwelling gregarines were detected in $10.5 \%$ of animals from the Nesvík site (Fig. 2c). The taxonomic identity of the gregarines is currently unknown. Morphologically, gregarines were elongate with no clearly discernible epimerite, contained an eosinophilic nucleus and nucleolus and a granular, light blue-staining cytoplasm. Gregarines were often present at high density throughout the gut of infected hosts (Fig. 2c). No host immune response was noted via histological observation to target these protists. Ciliated protists were present at relatively high prevalence in crabs collected from all sites, at an average prevalence of $84.5 \pm 10.0 \%$ (Table 4 ). Like those observed on the gills and appendages of specimens from the UK, ciliated protists from Faroese $C$. maenas were often present alongside filamentous bacteria and detritus and did not appear to elicit any pathology (or immune response) in their hosts. Hematodinium sp. were detected in crabs from 3 sites, at an average prevalence of $11.7 \pm 12.3 \%$ (Table 4). Parasites colonised the haemolymph (Fig. 2d), a feature reflected in the opaque, white haemolymph of infected crabs upon dissection. A nested PCR protocol provided a $345 \mathrm{bp}$ sequence including both the partial $18 \mathrm{~S}$ gene and internal transcribed spacer (ITS) region of a Hematodinium sp. infection from the Faroe Islands. BLASTn comparison of the sequence identified the $18 \mathrm{~S}$ region to have $100 \%$ similarity to Hematodinium sp. isolated from Chionoecetes opilio (accession: FJ844422; e-value = 2e-92). The ITS region showed closest similarity (95\%) to the same Hematodinium sp. isolated from C. opilio (accession: FJ844422; e-value $=7 \mathrm{e}-22$ ).

Infections by amoebae were detected in crabs from all Faroese sample sites, at an average prevalence of $12.6 \pm 6.9 \%$ (Table 4 ). Amoebae were observed in open circulation, often at the end of the lacunae of individual gill lamellae (Fig. 2e). In one case, amoebae appeared to contain cytoplasmic inclusions of unknown identity (Fig. 2e). Amoebae elicited no observable immune response from the host despite their presence in the haemolymph. Analysis of the SSU rRNA gene amplified from amoebae present within these infected crabs revealed two $100 \%$ matches (456 and $241 \mathrm{bp}$ ) and a single $99 \%$ match 


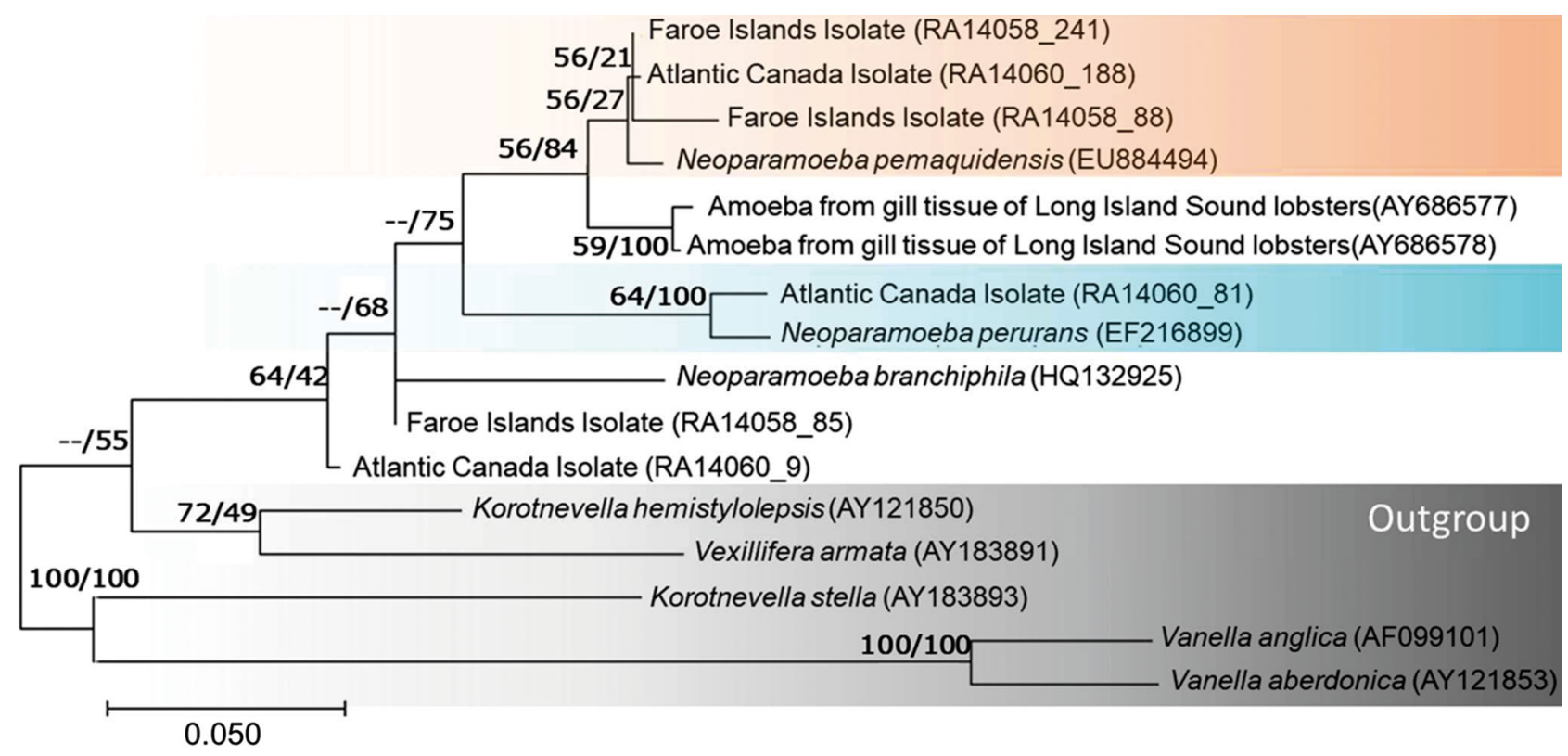

Fig. 4. Phylogenetic tree including representative isolates (Neoparamoeba pemaquidensis, N. branchiphila, N. perurans) and 18S sequences derived from the gill tissue of Carcinus maenas collected from the Faroe Islands and Atlantic Canada. Bootstrap values correspond to the neighbour-joining on the left and the maximum likelihood analysis on the right (NJ/ML); maximum likelihood tree is used to display the phylogeny. Orange box highlights those isolates that show high similarity to $N$. pemaquidensis; blue box highlights the isolate from Atlantic Canada with high similarity to N. perurans. The outgroup (grey box) is composed of 2 Vanella sp., Vexillifera armata, and 2 Korotnevella sp.

(399 bp) to Neoparamoeba pemaquidensis (EU88 4494), a parasite previously found infecting Atlantic salmon Salmo salar, sea urchins Strongylocentrotus droebachiensis and lobsters Homarus americanus. Phylogenetic comparison of these isolates to the closest available representative amoebae sequences showed an association with $N$. pemaquidensis to 2 of the isolates (56/21 bootstrap) ('RA14058_241' and 'RA14058_88'); however, the third isolate branched outside this group, closer to Neoparamoeba branchiphila (68 bootstrap) (Fig. 4). The true taxonomy of these amoebae requires further investigation.

The heart and skeletal muscle-infecting microsporidian resembling Ameson pulvis, detected in crabs from the UK, was also detected in crabs from 3 sites in the Faroe Islands, at an average prevalence of $1.7 \pm 2.0 \%$ (Table 4 ). Infection was confirmed by both histology and molecular phylogeny (amplification of the SSU rRNA gene provided a $901 \mathrm{bp}$ sequence with $99 \%$ similarity to N. carcini; accession: AF305708).

The bacterial infection termed 'milky disease' observed in UK crab populations was not observed in animals collected from the Faroe Islands. We did, however, detect a putative Rickettsia-like organism (RLO) in crabs from 2 sites, at an average prevalence of $4.0 \pm 7.0 \%$ (Table 4 ). The putative RLO appeared to colonise the skeletal muscles of the host, forming plaques at the periphery of muscle fibres in a region corresponding the sarcolemmal space. Colonies of bacteria could also be identified in histological section, present in the haemolymph. The presence of bacteria did not evoke a visible immune response from the host. Because the pathology extended to the muscle fibres, we have identified this as a different pathology from that related to milky disease.

Several viral pathogens were observed in crabs collected from Faroe Island sites. CmBV was present in the hepatopancreas of individuals from 3 sites, at an overall prevalence of $11.5 \pm 11.8 \%$ (Table 4). A putative parvo-like virus similar to that observed infecting crabs in the UK was detected in specimens collected from 2 sites in the Faroe Islands, at an average prevalence of $1.0 \pm 1.7 \%$ (Table 4 ). Only the nuclei of haemocytes were infected, resulting in nuclear hypertrophy due to the presence of an amorphous 'viroplasm' in the form of a Cowdry body. Under TEM, the viroplasm was packed with very small putative parvo-like virus particles, and though accurate measurement of individual virions was not possible, the pathology was consistent with the infection observed for the parvo-like virus in the UK (Fig. 3c,d). A novel irido-like virus was observed infecting crabs ( $\mathrm{n}=2,1.1 \%$ site prevalence) from the Nesvík site. Infection appeared to be restricted to the 

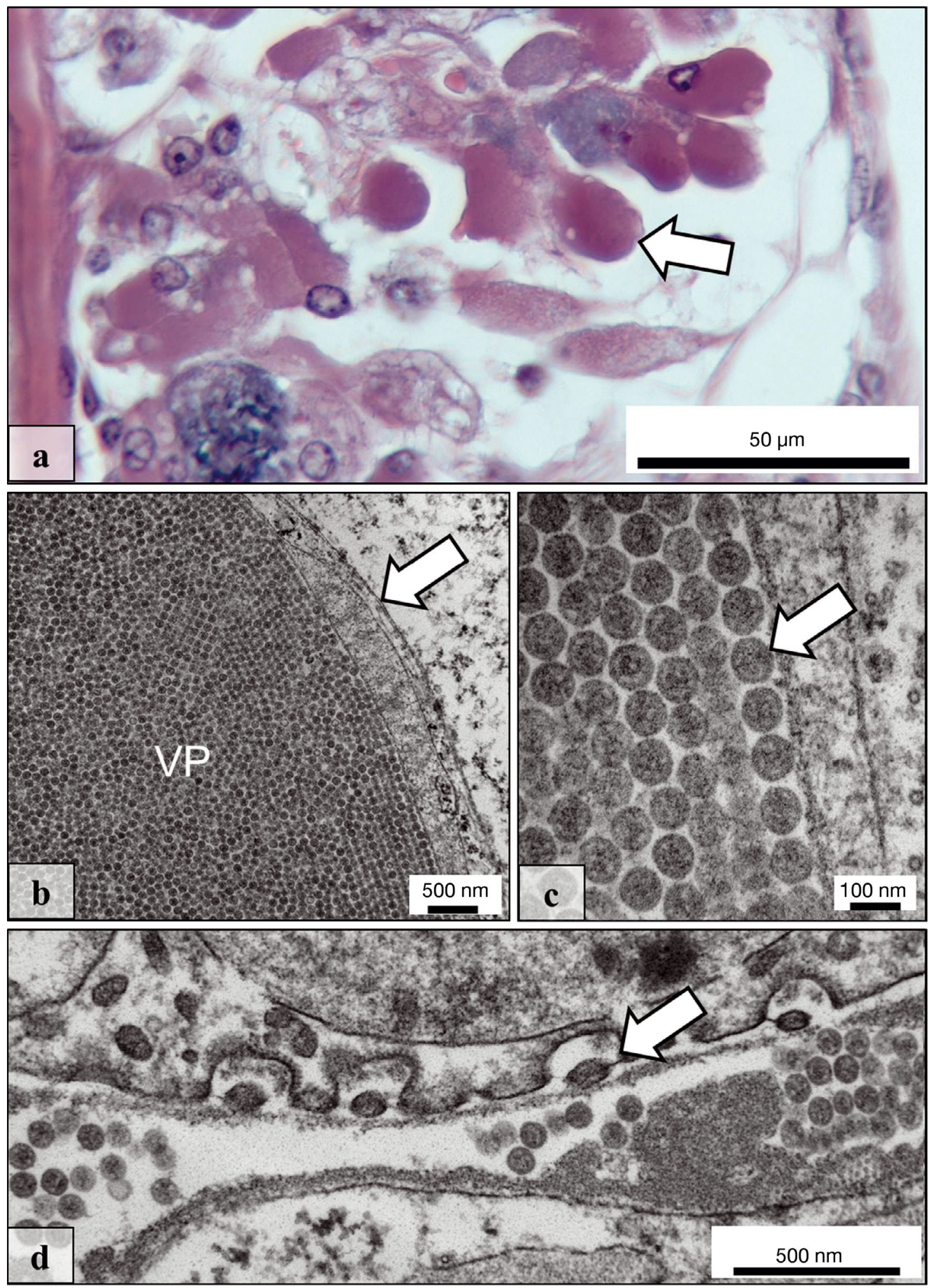

Fig. 5. Iridovirus from the cytoplasm of gill epithelia in Carcinus maenas from the Faroe Islands. (a) Histologically, the virus produced a deep-pink staining viroplasm (white arrow) in cells around the main gill stem. (b) Transmission micrographs show virions in a para-crystalline arrangement (VP) in the cytoplasm of infected cells, reaching the cell membrane (white arrow). (c) High magnification images revealed hexagonal virions (white arrow) arranged within the cytoplasm. (d) In late infections the virions were seen to move out of the host cell (white arrow) into the inter-cellular space 


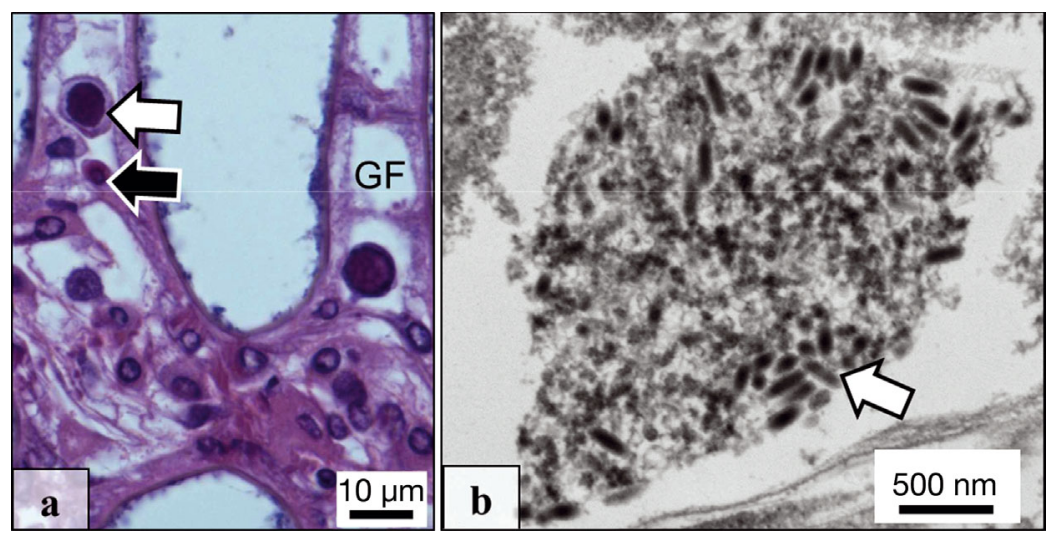

Fig. 6. A B-virus-like virus in the granulocytes of Carcinus maenas from the Faroe Islands. (a) Uninfected (black arrow) and infected (white arrow) granulocytes are present in the gill filament (GF). (b) Transmission micrograph from wax-embedded tissue revealed rod-shaped virions (white arrow) in the nucleus and cytoplasm of the host granulocytes

connective tissues and tegmental glands of the primary gill lamellae (Fig. 5a). Infection elicited a distinctive eosinophilic staining characteristic of infected host cells (Fig. 5a). Under TEM, individual virions were shown to measure $96.6 \pm 12.2 \mathrm{~nm}(\mathrm{n}=$ 50) in diameter, were arranged in a paracrystalline array (Fig. 5b,c) and occurred at high density in heavily infected cells. Individual virions were also observed transitioning through the membrane of infected cells (Fig. 5d). No immune response to infected host cells was observed via histology or TEM. Finally, a rod-shaped virus was detected infecting crabs collected from 3 sites, at an overall prevalence of $3.8 \pm 3.8 \%$ (Table 4). Histology revealed a deep-purple staining viroplasm in the infected nucleus of host haemocytes and hematopoietic organs (Fig. 6a). TEM revealed a rod-shaped virus, with potential synonymy with 'B-virus' described in European C. maenas by Bazin et al. (1974) (Fig. 6b). The TEM samples obtained in this study originated from wax-embedded materials originally fixed for histology. In this case, virions had the following dimensions: core width $=55.7 \pm 9.6 \mathrm{~nm}_{\text {; }}$ core length $=152.4 \pm 17.9 \mathrm{~nm}$; membrane width $=62.2 \pm$ $12.4 \mathrm{~nm}$; membrane length $=185.6 \pm 26.4 \mathrm{~nm}(\mathrm{n}=30)$. This viral infection elicited no observable immune response from the host.

\section{Nova Scotia}

Histological analyses revealed 13 symbionts in crabs collected from the shoreline of Nova Scotia. The survey revealed several organisms also detected in crabs from the UK and Faroe Islands but also a previously unreported microsporidian parasite and potential re-discovery of a viral pathogen previously detected in invasive $C$. maenas from US waters.

Metazoan parasites included an ectoparasitic crustacean infection in crabs collected from 3 sites at an average prevalence of $1.9 \pm 3.4 \%$ (Table 5). Ectoparasitic crustaceans colonised the space between gill lamellae, as was observed in crabs from the UK and Faroe Islands; further work is needed to define their species and symbiotic relationship. $P$. botulus was detected in crabs from 2 sites, at an average overall prevalence of $2.0 \pm 4.4 \%$, eliciting similar pathology to that observed at other geographic locations (Fig. 2a, Table 5). Trematodes belonging to the Microphallidae were recorded in crabs from all Canadian sites, except for Fox Point, at a prevalence of $11.5 \pm 9.2 \%$ (Table 5). A nematode infection was noted in a single specimen $(0.9 \%)$ sampled from the Pubnico site. Infection was localised to the connective tissues of the hepatopancreas (Fig. 2b). No immunological responses were observed via histology to target this parasite.

Micro-eukaryote symbionts were frequently observed. Ciliates (including stalked ciliates) were common upon the gills and carapaces of crabs collected from all Canadian sites, at an average prevalence of $62.9 \pm 22.7 \%$ (Table 5). Amoebae, similar to those detected in crabs from the Faroe Islands, were observed infecting crabs from 5 sites, at an average prevalence of $15.7 \pm 17.0 \%$ (Table 5 ). The location and histological appearance of amoebae was as described above (Fig. 2e,f). Analysis of the SSU rRNA gene sequence from amoebae infecting crabs $(n=3)$ from Atlantic Canada revealed potential for co-infection by 3 parasites closely related to $N$. pemaquidensis ('RA14060_188' [456 bp]; 99\% identity to AY714363), and 2 to $N$. perurans ('RA14060_81' [356 bp]; 99\% identity to EF216900 and 'RA14060_9' [256 bp]; $98 \%$ identity to KU985058). Both of these species have previously been reported as infections of $H$. americanus and $S$. salar, respectively (Mullen et al. 2004, 2005, Feehan et al. 2013). Phylogenetic comparison of the 3 Canadian amoebae isolates to those from the Faroe Islands and representative sequences identified one ('RA14060_188') associated with $N$. pemaquidensis and other Faroese samples, a second ('RA14060_81') branching alongside $N$. perurans, 


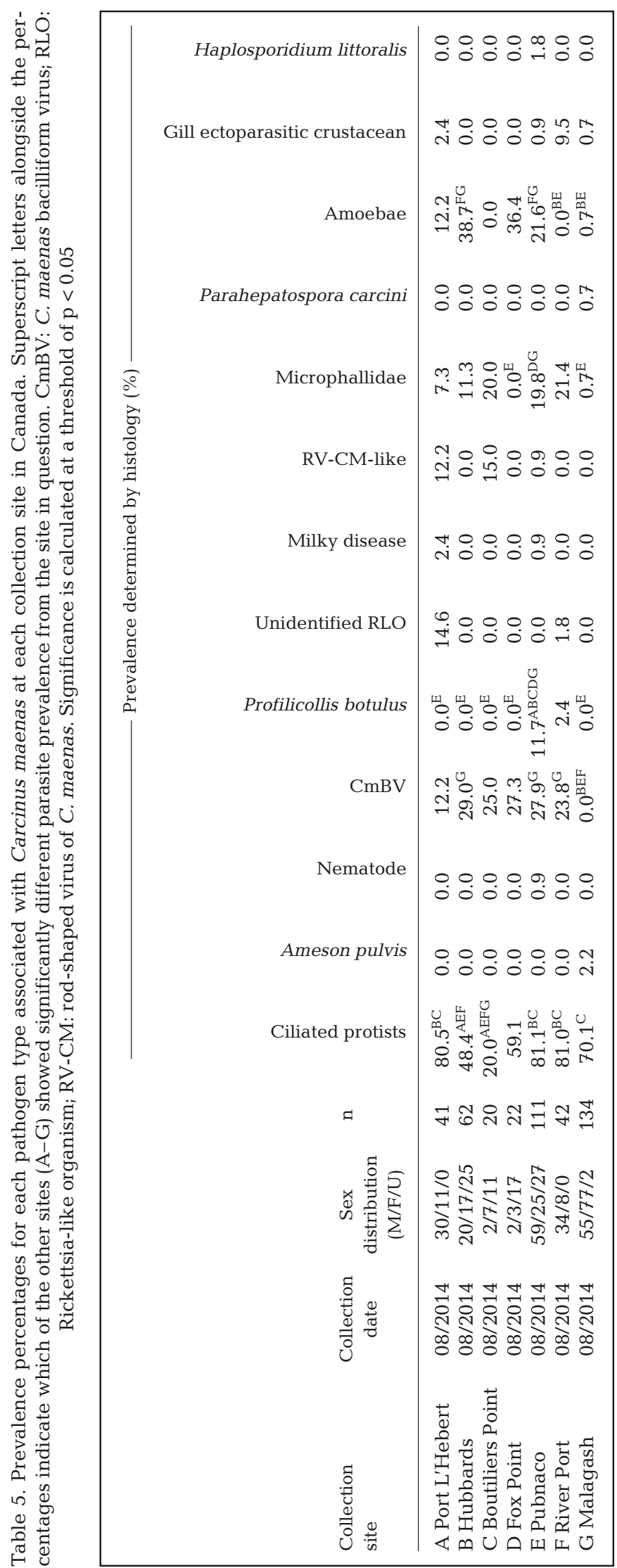

and a third isolate ('RA14060_9') at the base of the Neoparamoeba group (Fig. 4).

A haplosporidian resembling $H$. littoralis was detected infecting crabs from the Pubnico site, at low prevalence ( $\mathrm{n}=2,1.8 \%$ ). A microsporidian resembling A. pulvis was detected in $2.2 \%$ of crabs sampled from the Malagash site. A novel microsporidian parasite was detected infecting epithelial cells of the hepatopancreas of a single $C$. maenas $(0.7 \%)$ from the Malagash site. Using histology, TEM and phylogenetics data, the novel parasite was named Parahepatospora carcini n. gen. n. sp. in a separate paper from our group (Bojko et al. 2017a).

The putative RLO bacterial infection detected in crabs collected in the Faroe Islands was also observed infecting the musculature of $C$. maenas sampled from 2 Canadian sites at an average prevalence of $2.3 \pm$ $5.4 \%$ (Table 5). Infection manifested as bacterial plaques formed in the sarcolemmal space of infected muscle fibres. Immune responses were noted targeting plaques by an aggregation of granulocytes. Milky disease, as recorded in crabs from the UK, was also observed in crabs collected from 2 sites in Canada (0.5 $\pm 0.9 \%$ ) (Table 5). High burdens of bacterial cells in the haemolymph resulted in a thick, opaque, white haemolymph, visible during dissection. Histologically, infection manifested as large, purple-pink staining bacterial plaques within the haemolymph and fixed phagocytes of the hepatopancreas, often associated with haemocyte aggregation and melanisation.

Two viral pathogens were detected in crabs collected from Canadian sites. CmBV was observed infecting crabs from 6 of the collection sites $(20.7 \pm$ $10.7 \%$ ) (Table 5). Pathology associated with $\mathrm{CmBV}$ mirrored that observed in crabs collected from other geographic locations within this study. A rod-shaped virus was detected in crabs collected from 3 sites in Canada, at average prevalence across the Nova Scotia sample sites of $4.0 \pm 6.6 \%$ (Table 5). Histological analysis revealed a deep-purple staining viroplasm within the nuclei of haemocytes and hematopoietic tissues (Fig. 7a). TEM revealed a rod-shaped virus, resembling both the B-virus reported in European crabs and rod-shaped virus of C. maenas (RV-CM) from invasive populations in the USA (Johnson 1988) (Fig. 7b,c). Rod-shaped virions contained condensed genomic material and a protein capsid (Fig. 7d). Dimensions of the virions were as follows: core width $=100.3 \pm 13.3 \mathrm{~nm}$ core length $=245.6 \pm$ $42.1 \mathrm{~nm}$; membrane width $=219.8 \pm 36.3 \mathrm{~nm}$; membrane length $=306.2 \pm 34.7 \mathrm{~nm}(\mathrm{n}=30)$. This viral infection elicited no observable immune response via histology from the host. 

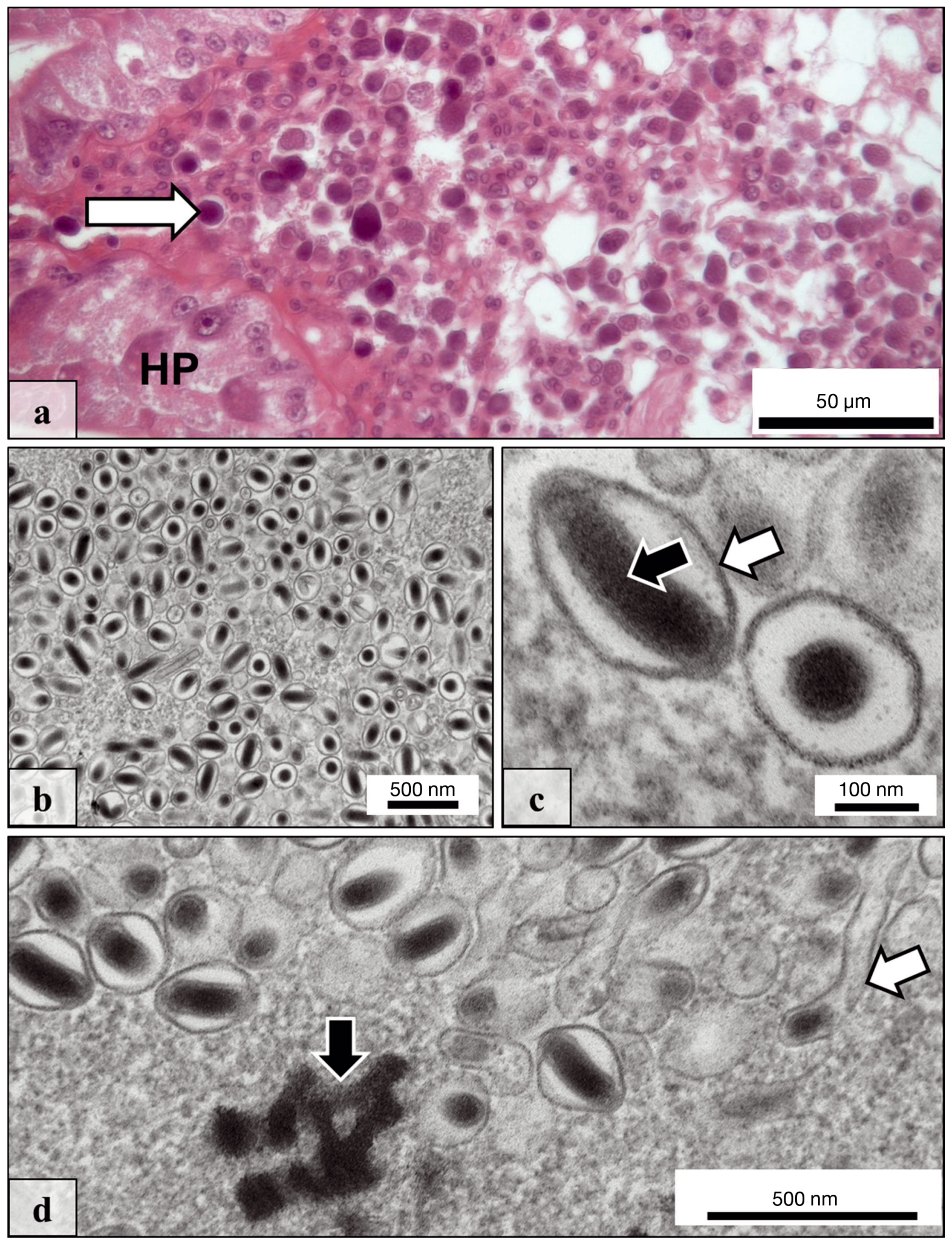

Fig. 7. Rod-shaped virus of Carcinus maenas (RV-CM)-like virus, an intranuclear rod-shaped virus from C. maenas collected from Atlantic Canada. (a) Histological sections identified granulocytes with hypertrophic, deep-purple-staining nuclei (white arrow) in the haemolymph around the hepatopancreas (HP). (b) Electron micrograph of an infected nucleus displaying several developmental stages of the RV-CM-like virus. (c) High magnification image of a transverse and longitudinal section of 2 virions, identifying the genomic core (black arrow) and lipid membrane (white arrow). (d) Developing genomic (black arrow) and lipid membrane (white arrow) material in the host nucleus 


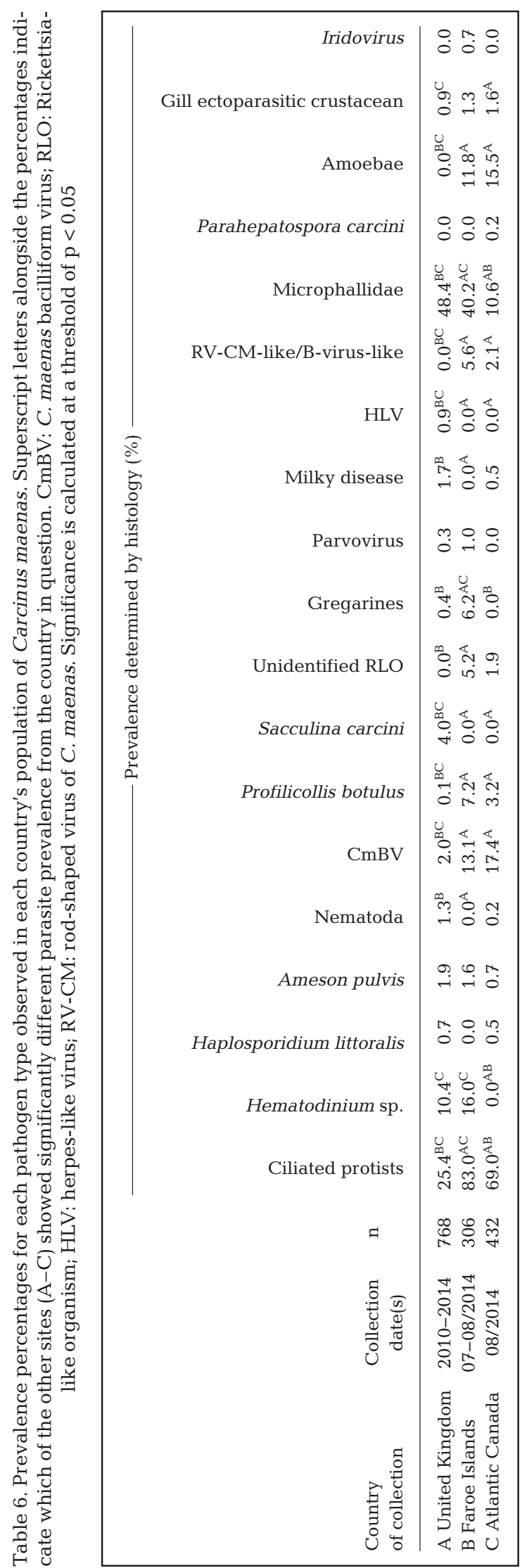

\section{Symbionts relative to the $C$. maenas invasion route}

Data pertaining to 19 symbiont associations from 1506 individual crabs collected from 23 sites (27 distinct sampling efforts; Table 1) in 3 distinctive geographical locations were utilised to compare combined symbiont profiles over a previously proposed invasion route of $C$. maenas from Northern Europe to Atlantic Canada (Table 6). Symbiont profiling revealed that discrete pathogens, parasites and commensals were shared between the 3 geographic locations (Table 6).

In addition to considering the distribution and prevalence of the various symbionts across the sample populations, the factor of host sex was also assessed in comparison to symbiont presence. Analysis identified that ciliates were more commonly associated with male $C$. maenas (chi-squared test, $\chi^{2}{ }_{1}=$ $15.341, \mathrm{p}<0.001), P$. botulus were more commonly associated with male $C$. maenas $\left(\chi^{2}{ }_{1}=4.4475, \mathrm{p}=\right.$ 0.035), and ectoparasitic crustaceans were more commonly associated with male $C$. maenas in the UK $\left(\chi^{2}{ }_{1}=6.0116, p=0.014\right)$. All other symbionts revealed no preference for a particular host sex. Both sexes showed a dissimilar co-infection rate, with males possessing a significantly greater number of symbionts (inhabited by more than one symbiont) than females, who tended to have less symbionts per individual crab (Wilcoxon test, $W=209470, \mathrm{p}=0.015$ ).

Using the Marascuilo procedure, an analysis was conducted to identify which symbionts were present at significantly different prevalence. This revealed a variety of significant associations detailed in Tables 3-6. Specifically, Hematodinium sp. was at a significantly higher prevalence in the Faroese population than the Canadian population $(\mathrm{p}<0.05)$ and the incidence of amoebae was significantly greater in the Canadian population relative to the other 2 countries $(\mathrm{p}<0.05)$. Ciliated protists were the most common symbiont in Canada and the Faroe Islands; however, members of the Microphallidae were most commonly observed in the UK (Table 6). Diseases that are considered as mortality inducing (Hematodinium sp., Microsporidia, viruses) were more common in the UK and Faroese populations (Table 6). The Canadian populations showed a lower incidence of Microsporidia $(0.7 \%)$ compared to the UK and Faroe Islands (1.9 and $1.6 \%$ respectively), along with a lower viral diversity. Amoebae in the Faroe Islands and Canada (associating with the fish and crustacean pathogens $N$. pemaquidensis and $N$. perurans) were at a significantly greater prevalence $(\mathrm{p}<0.05)$ than the UK. 


\section{DISCUSSION}

Biological invasions are commonly associated with the introduction of parasites and pathogens (Dunn \& Hatcher 2015); however, the success of those hitchhikers may be dependent on the invaders' success, the environment they are transferred to, or the susceptibility (to infection and disease) of native species (Vilcinskas 2015). Alternatively, invasive species can escape from their parasites and benefit from increased fitness (Torchin et al. 2001, Colautti et al. 2004, Blakeslee et al. 2013). The invasive host may also become a sink for native pathogens through acquisition, possibly leading to an increased threat of parasitism through 'spill-back' to native species and increased disease risk (Torchin et al. 2003, Blakeslee et al. 2009, Kelly et al. 2009).

The native range of Carcinus maenas is large, spanning from the Northern Atlantic Ocean around Northern Africa (Moroccan coast) and Central Europe up to the Baltic Sea around Northern Europe, including the isolated region of the Faroe Islands and Iceland (Darling et al. 2008). From there, populations have colonised almost every coastline around the globe (Blakeslee et al. 2010, Zetlmeisl et al. 2011), excluding the Antarctic and New Zealand (Garside et al. 2014). One invasion route of C. maenas includes movement from Northern Europe to Atlantic Canada (Darling et al. 2008). Accompanying this movement is the potential for symbiont transfer between marine habitats across a wide spatial and temporal dimension (Torchin et al. 2001, 2002).

Utilising an existing comprehensive histopathology data set relating to symbiont profiles of $C$. maenas in the UK, coupled with additional surveys from Faroese and Canadian populations of C. maenas, we investigated whether these populations differed in the prevalence of disease and whether they have transferred symbionts from their native range to the invasive range or acquired novel pathogens, which could potentially harm aquaculture, fisheries species and wildlife.

\section{Metazoans}

Several metazoan symbionts were identified in our study including crustaceans, nematodes, digeneans and acanthocephalans. Populations from all countries and sites were infected with a digenean resembling a member of the Microphallidae, trematodes with complex lifecycles involving snails, crustaceans and birds (Stunkard 1957). Despite the complexity of this lifecycle, this parasite is clearly adaptable to the specific conditions (invasive and native hosts) encountered at invasion sites, and previous studies have pre-defined that this parasite appears not to alter host physiology, but has some minimal effects on host behaviour and immunology (Blakeslee et al. 2015). Profilicollis botulus infections also persist in the novel range, but no studies have yet determined their impact upon the invasive host. No nematodes were detected in the Faroese populations, whilst infection in both the UK $(1 \%)$ and Canada $(<1 \%)$ was infrequent. It is likely these are opportunistic infections; however, no molecular evidence is available to discern their taxonomy.

Ectoparasitic crustaceans were detected on the gills of C. maenas, via histology, from each country at low average prevalence ( 1 to $2 \%$ ). No genetic data or whole animal images are available to identify these ectoparasites, however it is assumed they could be one of the several isopod species identified from this host (Shields et al. 2015). In future visits to these ranges, it is important to dissect individual crabs and prepare these ectoparasites for formal identification.

The reduced infection pressure due to the absence of Sacculina carcini may benefit C. maenas populations in Canada, and this parasite has been reported as a potential biological control agent (Torchin et al. 2003, Goddard et al. 2005, Kuris et al. 2005). S. carcini castrates and parasitizes its host, resulting in a combination of pathogen-based biocontrol with the added benefits of autocidal control (Goddard et al. 2005, Zetlmeisl et al. 2011). Zetlmeisl et al. (2011) determined that Sacculina sp. decrease gonad size in their host and alter fecundity. Significant drawbacks include an unknown range of host specificity; an issue with many potential biocontrol agents (Goddard et al. 2005). This link to biological control has also been explored/assessed for several other symbionts (Kuris et al. 2005), including many microbial parasites.

The control of invasive C. maenas is of paramount importance to prevent its further spread and effect upon native ecologies. Recent physical control attempts (circa 2008), such as the removal of over 350000 crabs from around Newfoundland, have proven ineffective due to continued observations of C. maenas spread (Blakeslee et al. 2010). Understanding parasite loss, and determining opportunities for control, remain an important research effort.

\section{Microbial eukaryotes}

Dinoflagellates, haplosporidians, microsporidians, ciliates and apicomplexans have all previously been 
observed in the UK population of C. maenas (Stentiford \& Feist 2005, Stentiford et al. 2013a,b). This study has confirmed that ciliated protists, Hematodinium sp., Ameson pulvis, amoebae (Neoparamoeba perurans-like and $N$. pemaquidensis-like) and gregarines occur in C. maenas populations in the Faroe Islands. The Canadian populations also harbour ciliated protists, a haplosporidian resembling Haplosporidium littoralis $(<1 \%)$, A. pulvis $(<1 \%)$, a $N$. pemaquidensis-like/N. perurans-like amoebae $(15.5 \%)$ and a novel microsporidian parasite recently described as Parahepatospora carcini $(<1 \%)$ (Bojko et al. 2017a).

The parasitic dinoflagellate Hematodinium sp. was detected in both the UK and Faroese populations at 10 and $16 \%$ prevalence respectively. In contrast, the parasite was not detected in the Canadian population, despite similar parasites known to infect native crustacean hosts from the Canadian marine environment (Shields et al. 2005). These dinoflagellate parasites are considered mortality drivers in crustacean populations, causing systemic infections that result in milky haemolymph, organ failure and eventually, host death (Shields \& Squyars 2000). The host range of Hematodinium perezi (type host C. maenas) incorporates several crustacean hosts (MacLean \& Ruddell 1978, Small et al. 2012, Sullivan et al. 2016, O'Leary \& Shields 2017). The absence of $H$. perezi infection in Canadian C. maenas may reflect true absence of this pathogen in its invasive range and possibly parasite release from its effects (Torchin et al. 2003). However, given the pronounced seasonality of infection prevalence of Hematodinium dinoflagellates, repeat sampling of Canadian crabs in winter or spring would clarify the situation.

The amoebae detected during this study may have originated from the invasive range of $C$. maenas given that similar infections have not been detected to date in the UK population. Several of our sample sites from the Faroese and Canadian territories were close to salmon and bivalve aquaculture operations. Whether the infection in crabs is synonymous with parasites known to infect salmon, where various Neoparamoeba spp. have been implicated in amoebic gill disease (AGD) (Douglas-Helders et al. 2003, Feehan et al. 2013), remains to be shown. The detection of Neoparamoeba spp. in invasive C. maenas populations from Canada (16\% prevalence) could be the result of a 'spill-over' event, given that Neoparamoeba sp. has been identified as the agent of a lethal disease of lobsters and sea urchins (Mullen et al. 2004, 2005). Alternatively, and perhaps more likely, infections in fish may result from transfer from reservoirs in marine invertebrate hosts such as $C$. maenas. The presence of this pathogen group in $C$. maenas populations without visible immunological response (as diagnosed via histology) or disease features suggests they are asymptomatic and a carrier of the disease. Work is now required to investigate synonymy between the pathogen detected in C. maenas and that known to infect Homarus americanus (Mullen et al. 2004, 2005).

\section{Viruses and bacteria}

UK populations of $C$. maenas harboured 3 viruses ( $\mathrm{CmBV}$, parvo-like virus, HLV) and a bacterial disease (milky disease). Milky disease is considered to cause mortality in crustaceans, resulting in systemic infections and milky haemolymph, but can be caused by a range of bacterial taxa (Eddy et al. 2007). The aetiological agent of a clinical disease resembling milky disease may therefore differ between geographic locations. In addition to observations of milky disease, filamentous bacteria were observed on the gills in some specimens with identical pathology to that noted by Stentiford \& Feist (2005). Whether these are bacterial or not requires greater clarification, as recent evidence suggests a possible link to the Mesomycetozoea (Shields et al. 2015).

In contrast, the viral infections observed in the UK C. maenas are caused by specific agents: $\mathrm{CmBV}$ infecting the nuclei of the hepatopancreas (Stentiford \& Feist 2005), a putative parvo-like virus infecting the nuclei of gill epithelia and haemocytes (first reported here), and HLV infecting the nuclei of haemocytes (Bateman \& Stentiford 2017).

HLV was only detected in populations of crabs from the UK and at low prevalence $(<1 \%)$, specifically in samples collected during the summer months from the Weymouth site. The apparent seasonality and site specificity of this infection may be responsible for its apparent absence from C. maenas within the invasive range. Further, it may require suitable environmental and host-health conditions (temperature, stress) for infection, transmission and spread. Alternatively, it may be prevalent in juveniles of $C$. maenas, a phenomenon noted for other haemocyte viruses of crustaceans (Shields \& Behringer 2004).

The putative parvo-like virus was detected at low prevalence $(<1 \%)$ in crabs from both the UK and Faroese populations. Detection in the UK (Weymouth) occurred during winter, once again suggesting seasonality in susceptibility of crabs in the native range. Faroese populations, residing in cooler waters 
than those of the majority of UK sites, were infected at approximately $1 \%$ apparent prevalence. This virus was not detected in Canadian populations. Further assessment of the effects of water temperature on this pathogen would be informative.

In the Faroe Islands a putative iridovirus was detected at low prevalence $(1 \%)$, however little is known about this virus other than the pathology and ultrastructure presented in this study. Genomic sequencing is now required to identify this virus.

In both the Faroese and Canadian populations a rod-shaped virus was also detected. The virus resembled B-virus, detected in crabs from mainland Europe (Bazin et al. 1974) and RV-CM, a virus reported infecting invasive C. maenas from the Atlantic coast of the USA (Johnson 1988). Morphologically, these viruses resemble white spot syndrome virus (WSSV) (Nimaviridae), an important pathogen of farmed penaeids (Stentiford et al. 2017), with a potentially wide host range (Stentiford et al. 2009). Given that the rod-shaped virus detected here shares pathological characteristics with WSSV, further studies are required to investigate both the phylogeny of these pathogens of temperate water crustaceans and the potential susceptibility of native crustacean hosts in Canada, such as $H$. americanus, which is known to be susceptible to WSSV (Clark et al. 2013).

\section{Potential impact of $C$. maenas symbionts on native fauna in Canada}

Atlantic Canada boasts a highly successful aquaculture and fisheries industry worth an overall $\$ 6.6$ billion USD in 2016, including a lobster fishery that alone was worth over $\$ 2.0$ billion USD in 2016 (DFO $2017 \mathrm{~b}$ ). The invasion of $C$. maenas and its pathogens has the potential to pose significant risk to this sector, especially in the light of the use of this invader as a bait source to catch lobster and other species (Bojko et al. 2017a).

C. maenas has impacted aquaculture through competition and predation (Therriault et al. 2008). Our results have identified that this invader carries pathogens that could transfer to species exploited by fishery and aquaculture industries. Specifically, this includes shared bacterial pathogens (Aerococcus viridans var. hommari; Smith \& Ratcliffe 1978) and acanthocephala (Brattey \& Campbell 1986), with the potential for further transfer of related amoebae (Mullen et al. 2005) and viral pathogens (i.e. B-virus/RV-CM) to American lobster (Clark et al. 2013). Further, they have the potential to pose a significant threat to native fauna via the introduction of novel pathogens, or by acting as a reservoir for native pathogens.

C. maenas may also obtain pathogens from native hosts. Our survey identified $P$. carcini, a rare microsporidian pathogen that may have been acquired from native crustacean fauna due to its apparent absence from widely sampled populations in the native range (Bojko et al. 2017a). It is possible that $C$. maenas acts a reservoir for such native pathogens, allowing the numbers of pathogens (such as amoebae and Microsporidia) to build up and to spill back into native populations, possibly resulting in increased host mortality (Kelly et al. 2009, Bojko et al. 2017a). Other pathogens, including those morphologically and pathologically similar to the haemocyte-infecting rod-shaped virus RV-CM (similar to that described by Johnson 1988), have been associated with mortality in other farmed and fished crustaceans (Bateman \& Stentiford 2017). One of the most economically devastating pathogens is WSSV. Given that the host range of WSSV is wide, encompassing some native Canadian species such as $H$. americanus (Clark et al. 2013), the potential for transmission of RV-CM between Canadian C. maenas and other susceptible hosts should be investigated.

In conclusion, the use of C. maenas as a bait source for the commercial fishery for lobster has the potential to facilitate pathogen and parasite transmission to this host, based on the diversity of symbionts carried by this invader. Observation of pathogens previously associated with disease in lobsters (e.g. Neoparamoeba sp.) (Mullen et al. 2004, 2005) requires greater attention, and the presence of such pathogens in burgeoning populations of $C$. maenas could result in a repeat mortality event, as observed by Mullen et al. $(2004,2005)$. Although the formal Canadian response to the green crab invasion has largely been to measure and study its ecological disturbance to native species through destruction of eel grass beds (Garbary et al. 2014) and consumption of prey species (Gregory \& Quijón 2011), little focus has been spent on the risk of pathogen transfer to native species in Canada. This study demonstrates the importance of including comprehensive pathogen surveys when assessing the risk of a new invasive species in a new region, instead of solely focusing on ecological impacts. Current work by our respective laboratories now aims to conduct a risk assessment, provide education and inform policy on the potential of disease transfer when using this species as a bait source, suggesting safer alternatives as bait to capture lobster and to prevent possible disease transfer and maintain the health of the fishery. 
Acknowledgements. This work constitutes part of J.B.'s PhD thesis from the University of Leeds. The authors acknowledge funding from NERC and Cefas to A.M.D. and J.B. (\#:1368300) and the European Commission and UK Department for Environment, Food and Rural Affairs under contracts FB002, C6928 and DP227x to G.D.S. We thank Brad Elliott (Dalhousie University), Stephanie Hall (Dalhousie University) and Rory Clark for their help in collecting and fixing specimens, Stuart Ross (Cefas) for TEM advice and Matthew Green (Cefas) for histological and chemical transport advice. Thanks to Martin S. J. Rogers for development of Fig. 1, and the authors wish him good luck for his Master's Degree result. Carcinus maenas were collected under the Department of Fisheries and Oceans Canada scientific licence SG-RHQ-144-068.

\section{LITERATURE CITED}

Bateman KS, Stentiford GD (2017) A taxonomic review of viruses infecting crustaceans with an emphasis on wild hosts. J Invertebr Pathol 147:86-110

Bazin F, Monsarrat P, Bonami JR, Croizier G, Meynadier G, Quiot JM, Vago C (1974) Articles virales de type Bacilovirus observées chez le crabe Carcinus maenas. Rev Trav Inst Peches Marit 38:205-208

Blakeslee AMH, Keogh CL, Byers JE, Kuris AM, Lafferty KD, Torchin ME (2009) Differential escape from parasites by two competing introduced crabs. Mar Ecol Prog Ser 393:83-96

Blakeslee $\mathrm{AMH}, \mathrm{McKenzie} \mathrm{CH}$, Darling JA, Byers JE, Pringle JM, Roman J (2010) A hitchhiker's guide to the Maritimes: anthropogenic transport facilitates long distance dispersal of an invasive marine crab to Newfoundland. Divers Distrib 16:879-891

Blakeslee AM, Fowler AE, Keogh CL (2013) Marine invasions and parasite escape: updates and new perspectives. Adv Mar Biol 66:87-169

Blakeslee AM, Keogh CL, Fowler AE, Griffen BD (2015) Assessing the effects of trematode infection on invasive green crabs in eastern North America. PLOS ONE 10: e0128674

Bojko J, Clark F, Bass D, Dunn AM, Stewart-Clark S, Stebbing PD, Stentiford GD (2017a) Parahepatospora carcini n. gen., n. sp., a parasite of invasive Carcinus maenas with intermediate features of sporogony between the enterocytozoon clade and other Microsporidia. J Invertebr Pathol 143:124-134

Bojko J, B cela-Spychalska K, Stebbing PD, Dunn AM, Grabowski M, Rachalewski M, Stentiford GD (2017b) Parasites, pathogens and commensals in the 'low-impact' non-native amphipod host Gammarus roeselii. Parasit Vectors 10:193

Bourdon R (1965) Inventaire de la faune marine de Roscoff: décapodes-stomatopodes. Editions de la Station Biologique de Roscoff, Roscoff

Brattey J, Campbell A (1986) A survey of parasites of the American lobster, Homarus americanus (Crustacea: Decapoda), from the Canadian Maritimes. Can J Zool 64: 1998-2003

Chatton E, Lwoff A (1935) Les ciliés apostomes I. Arch Zool Exp Gén 77:1-453

Clark KF, Greenwood SJ, Acorn AR, Byrne PJ (2013) Molecular immune response of the American lobster (Homarus americanus) to the white spot syndrome virus. J Invertebr Pathol 114:298-308
Colautti RI, Ricciardi A, Grigorovich IA, MacIsaac HJ (2004) Is invasion success explained by the enemy release hypothesis? Ecol Lett 7:721-733

* Comely CA, Ansell AD (1989) The occurrence of black necrotic disease in crab species from the west of Scotland. Ophelia 30:95-112

Couch JA (1983) Diseases caused by Protozoa. In: Provenzano AJ Jr (ed) The biology of the Crustacea, Vol 6: pathobiology. Academic Press, New York, NY, p 79-111

Crooks JA (2002) Characterizing ecosystem level consequences of biological invasions: the role of ecosystem engineers. Oikos 97:153-166

Cuénot L (1895) Études physiologiques sur les crustacés décapodes. Arch Biol (Liege) 13:245-303

* Darling JA, Bagley MJ, Roman J, Tepolt CK, Geller JB (2008) Genetic patterns across multiple introductions of the globally invasive crab genus Carcinus. Mol Ecol 17: 4992-5007

DFO (Fisheries and Oceans Canada) (2017a) Scientific licences - coastal Pacific region. www.pac.dfo-mpo.gc. $\mathrm{ca} / \mathrm{fm}$-gp/licence-permis/sci/index-eng.html (accessed 24 Aug 2017)

DFO (2017b) Monitoring results. www.dfo-mpo.gc.ca/fmgp/sustainable-durable/fisheries-peches/species-especeseng.htm (accessed 24 Aug 2017)

Douglas-Helders GM, Handlinger JH, Carson J, Nowak BF (2003) Assessment over time of the infectivity of gillderived and seawater dispersed Neoparamoeba pemaquidensis (Page, 1987). Bull Eur Assoc Fish Pathol 23: 35-39

Duerden JE (1893) On some new and rare Irish Polyzoa. Proc R Ir Acad 3:121-136

* Dunn AM, Hatcher MJ (2015) Parasites and biological invasions: parallels, interactions, and control. Trends Parasitol 31:189-199

Eddy F, Powell A, Gregory S, Nunan LM and others (2007) A novel bacterial disease of the European shore crab, Carcinus maenas - molecular pathology and epidemiology. Microbiology 153:2839-2849

* Feehan CJ, Johnson-Mackinnon J, Scheibling RE, LauzonGuay JS, Simpson AGB (2013) Validating the identity of Paramoeba invadens, the causative agent of recurrent mass mortality of sea urchins in Nova Scotia, Canada. Dis Aquat Org 103:209-227

*Felsenstein J (1985) Confidence limits on phylogenies: an approach using the bootstrap. Evolution 39:783-791

*Garbary DJ, Miller AG, Williams J, Seymour NR (2014) Drastic decline of an extensive eelgrass bed in Nova Scotia due to the activity of the invasive green crab (Carcinus maenas). Mar Biol 161:3-15

Garside CJ, Glasby TM, Coleman MA, Kelaher BP, Bishop MJ (2014) The frequency of connection of coastal water bodies to the ocean predicts Carcinus maenas invasion. Limnol Oceanogr 59:1288-1296

*Goddard JH, Torchin ME, Kuris AM, Lafferty KD (2005) Host specificity of Sacculina carcini, a potential biological control agent of the introduced European green crab Carcinus maenas in California. Biol Invasions 7:895-912

Gregory GJ, Quijón PA (2011) The impact of a coastal invasive predator on infaunal communities: assessing the roles of density and a native counterpart. J Sea Res 66: $181-186$

Hall MC (1929) Arthropods as intermediate hosts of helminths. Smithsonian Miscellaneous Collections, Vol 81. Smithsonian Institution, Washington, DC 
Hopwood D (1996) Theory and practice of histopathological techniques. In: Bamcroft JD, Stevens A (eds) Fixation and fixatives, $4^{\text {th }}$ edn. Churchill Livingstone, Hong Kong, p 23-46

James BL (1969) The Digenea of the intertidal prosobranch, Littorina saxatilis (Olivi). J Zoological Syst Evol Res 7: 273-316

Johnson PT (1988) Rod-shaped nuclear viruses of crustaceans: hemocyte-infecting species. Dis Aquat Org 5: 111-122

Kelly DW, Paterson RA, Townsend CR, Poulin R, Tompkins DM (2009) Parasite spillback: A neglected concept in invasion ecology? Ecology 90:2047-2056

Kumar S, Stecher G, Tamura K (2016) MEGA7: molecular evolutionary genetics analysis version 7.0 for bigger datasets. Mol Biol Evol 33:1870-1874

Kuris AM, Lafferty KD, Torchin ME (2005) Biological control of the European green crab, Carcinus maenas: natural enemy evaluation and analysis of host specificity. In: $2^{\text {nd }}$ Int Symp Biological Control of Arthropods, 12-16 September 2005, Davos. USDA Forest Service Publication FHTET-2005-08, Riverside, CA, p 102-115

MacLean SA, Ruddell CL (1978) Three new crustacean hosts for the parasitic dinoflagellate Hematodinium perezi (Dinoflagellata: Syndinidae). J Parasitol 64:158-160

McIntosh WC (1865) The trematode larvae and Ascaris of the Carcinus maenas. Q J Microsc Sci 5:201-204

Monticelli FS (1890) Elenco degli elminti studiati a Wimereux nella primavera del 1889. Bull Biol Fr Belg 4: 417-444

Moravec F (2007) Some aspects of the taxonomy and biology of adult spirurine nematodes parasitic in fishes: a review. Folia Parasitol 54:239-257

Mullen TE, Russell S, Tucker MT, Maratea JL and others (2004) Paramoebiasis associated with mass mortality of American lobster Homarus americanus in Long Island Sound, USA. J Aquat Anim Health 16:29-38

Mullen TE, Nevis KR, O'Kelly CJ, Gast RJ, Frasca S (2005) Nuclear small-subunit ribosomal RNA gene-based characterization, molecular phylogeny and PCR detection of the Neoparamoeba from western Long Island Sound lobster. J Shellfish Res 24:719-731

Nei M, Kumar S (2000) Molecular evolution and phylogenetics. Oxford University Press, New York, NY

O'Leary PA, Shields JD (2017) Fiddler crabs (Uca spp.) as model hosts for laboratory infections of Hematodinium perezi. J Invertebr Pathol 143:11-17

Perkins EJ (1967) Some aspects of the biology of Carcinus maenas (L). Trans J Proc Dumfries Galloway Nat Hist Antiq Soc 44:47-56

Pina S, Russell-Pinto F, Rodrigues P (2011) Description of Maritrema portucalensis sp. nov. (Digenea, Microphallidae) parasite of Carcinus maenas (Crustacea, Decapoda) from Aveiro estuary, northern Portugal. Acta Parasitol 56:377-384

* Prévot G, Deblock S (1970) Contribution à l'étude des Microphallidae Travassos, 1920 (Trematoda) XX. Megalophallus carcini $\mathrm{n}$. sp., adulte expèrimental d'une métacercaire de Carcinus maenas Pennant. Ann Parasitol Hum Comp 45:213-222

R Core Team (2014) R: a language and environment for statistical computing. R Foundation for Statistical Computing, Vienna

Rankin JS Jr (1940) Studies on the trematode family Microphallidae Travassos, 1921. II. The genus Spelotrema
Jaegerskiold, 1901, and description of a new species, Spelotrema papillorobusta. Trans Am Microsc Soc 59: 38-47

Reynolds ES (1963) The use of lead citrate at high pH as an electron-opaque stain in electron microscopy. J Cell Biol $17: 208-212$

Richard J (1899) Essai sur les parasites et les commensaux de Crustacés. Arch Parasit 2:548-595

Roy HE, Hesketh H, Purse BV, Eilenberg J and others (2017) Alien pathogens on the horizon: opportunities for predicting their threat to wildlife. Conserv Lett 10:477-484

* Saitou N, Nei M (1987) The neighbor-joining method: a new method for reconstructing phylogenetic trees. Mol Biol Evol 4:406-425

* Shields JD, Behringer DC Jr (2004) A new pathogenic virus in the Caribbean spiny lobster Panulirus argus from the Florida Keys. Dis Aquat Org 59:109-118

Shields JD, Squyars CM (2000) Mortality and hematology of blue crabs, Callinectes sapidus, experimentally infected with the parasitic dinoflagellate Hematodinium perezi. Fish Bull 98:139-152

* Shields JD, Taylor DM, Sutton SG, O'Keefe PG, Ings DW, Pardy AL (2005) Epidemiology of bitter crab disease (Hematodinium sp.) in snow crabs Chionoecetes opilio from Newfoundland, Canada. Dis Aquat Org 64: 253-264

Shields JD, Boyko CB, Williams JD (2015) Parasites and pathogens of Brachyura. In: Castro P, Davie PJF, Guinot D, Schram FR, von Vaupel Klein (eds) The Crustacea: treatise on zoology - anatomy, taxonomy, biology, Vol 9, Part C-II Decapoda: Brachyura (Part 2). Brill, Boston, MA, p 639-774

Sindermann CJ (1990) Principal diseases of marine fish and shellfish, Vol 2: Diseases of marine shellfish, 2nd edn. Academic Press, New York, NY, p 93-144

Small HJ, Shields JD, Reece KS, Bateman K, Stentiford GD (2012) Morphological and molecular characterization of Hematodinium perezi (Dinophyceae: Syndiniales), a dinoflagellate parasite of the harbour crab, Liocarcinus depurator. J Eukaryot Microbiol 59:54-66

Smith VJ, Ratcliffe NA (1978) Host defence reactions of the shore crab, Carcinus maenas (L.), in vitro. J Mar Biol Assoc UK 58:367-379

Stebbing PD, Pond MJ, Peeler E, Small HJ, Greenwood SJ, Verner-Jeffreys D (2012) Limited prevalence of gaffkaemia (Aerococcus viridans var. homari) isolated from wild-caught European lobsters Homarus gammarus in England and Wales. Dis Aquat Org 100:159-167

Stentiford GD, Feist SW (2005) A histopathological survey of shore crab (Carcinus maenas) and brown shrimp (Crangon crangon) from six estuaries in the United Kingdom. J Invertebr Pathol 88:136-146

* Stentiford GD, Feist SW, Bateman KS, Hine PM (2004) Haemolymph parasite of the shore crab Carcinus maenas: pathology, ultrastructure and observations on crustacean haplosporidians. Dis Aquat Org 59:57-68

Stentiford GD, Bonami JR, Alday-Sanz V (2009) A critical review of susceptibility of crustaceans to Taura syndrome, yellowhead disease and white spot disease and implications of inclusion of these diseases in European legislation. Aquaculture 291:1-17

Stentiford GD, Bateman KS, Feist SW, Chambers E, Stone DM (2013a) Plastic parasites: extreme dimorphism creates a taxonomic conundrum in the phylum Microsporidia. Int J Parasitol 43:339-352 
Stentiford GD, Bateman KS, Stokes NA, Carnegie RB (2013b) Haplosporidium littoralis sp. nov.: a crustacean pathogen within the Haplosporida (Cercozoa, Ascetosporea). Dis Aquat Org 105:243-252

Stentiford GD, Sritunyalucksana K, Flegel TW, Williams BA, Withyachumnarnkul B, Itsathitphaisarn O, Bass D (2017) New paradigms to help solve the global aquaculture disease crisis. PLOS Pathog 13:e1006160

Stunkard HW (1957) The morphology and life-history of the digenetic trematode, Microphallus similis (Jagerskiold, 1900) Baer, 1943. Biol Bull (Woods Hole) 112:254-266

Sullivan TJ, Gelpi CG, Neigel JE (2016) Molecular detection of the parasitic dinoflagellate Hematodinium perezi from blue crabs Callinectes sapidus in Louisiana, USA. Dis Aquat Org 120:83-88

Tamura K (1992) Estimation of the number of nucleotide substitutions when there are strong transition-transversion and G + C-content biases. Mol Biol Evol 9:678-687

Therriault TW, Herborg LM, Locke A, McKindsey CW and others (2008) Risk assessment for European green crab (Carcinus maenas) in Canadian waters (No. 2008/042). DFO, Ottawa

Torchin ME, Lafferty KD, Kuris AM (2001) Release from parasites as natural enemies: increased performance of a globally introduced marine crab. Biol Invasions 3: 333-345

Torchin ME, Lafferty KD, Kuris AM (2002) Parasites and marine invasions. Parasitology 124:137-151

Editorial responsibility: Jeffrey Shields,

Gloucester Point, Virginia, USA
Torchin ME, Lafferty KD, Dobson AP, McKenzie VJ, Kuris AM (2003) Introduced species and their missing parasites. Nature 421:628-630

* Tourtip S, Wongtripop S, Stentiford GD, Bateman KS and others (2009) Enterocytozoon hepatopenaei sp. nov. (Microsporidia: Enterocytozoonidae), a parasite of the black tiger shrimp Penaeus monodon (Decapoda: Penaeidae): fine structure and phylogenetic relationships. J Invertebr Pathol 102:21-29

*Vilcinskas A (2015) Pathogens as biological weapons of invasive species. PLOS Pathog 11:e1004714

*Vivares CP (1971) Études des parasites des Crustacés Décapodes Brachyoures: Nemertes et larves Cestodes. Ann Parasitol Hum Comp 46:1-9

von Linstow O (1878) Compendium der Helminthologie, Vol 1. Hahn'sche Buchhandlung, Hannover, p 112-376

*Vossbrinck CR, Andreadis TG, Debrunner Vossbrinck BA (1998) Verification of intermediate hosts in the life cycles of microsporidia by small subunit rDNA sequencing. J Eukaryot Microbiol 45:290-292

*Young ND, Crosbie PBB, Adams MB, Nowak BF, Morrison RN (2007) Neoparamoeba perurans n. sp., an agent of amoebic gill disease of Atlantic salmon (Salmo salar). Int J Parasitol 37:1469-1481

Zetlmeisl C, Hermann J, Petney T, Glenner H, and others (2011) Parasites of the shore crab Carcinus maenas (L.): implications for reproductive potential and invasionsuccess. Parasitology 138:394-401

Submitted: September 11, 2017; Accepted: February 1, 2018 Proofs received from author(s): April 17, 2018 